\title{
Article \\ The Root Microbiome of Salicornia ramosissima as a Seedbank for Plant-Growth Promoting Halotolerant Bacteria
}

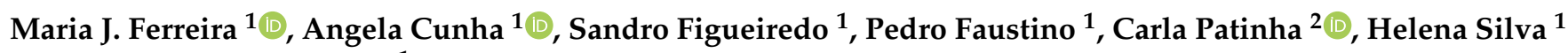 \\ and Isabel N. Sierra-Garcia ${ }^{1, *}$ \\ 1 Department of Biology and CESAM, University of Aveiro, Campus de Santiago, 3810-193 Aveiro, Portugal; \\ mjoaovf@ua.pt (M.J.F.); acunha@ua.pt (A.C.); sandrofigueiredo@ua.pt (S.F.); pdrfaustino@gmail.com (P.F.); \\ hsilva@ua.pt (H.S.) \\ 2 Department of Geosciences and Geobiotec, University of Aveiro, Campus de Santiago, \\ 3810-193 Aveiro, Portugal; cpatinha@ua.pt \\ * Correspondence: inatalia.sierra@ua.pt
}

check for updates

Citation: Ferreira, M.J.; Cunha, A.; Figueiredo, S.; Faustino, P.; Patinha, C.; Silva, H.; Sierra-Garcia, I.N. The Root Microbiome of Salicornia ramosissima as a Seedbank for Plant-Growth Promoting Halotolerant Bacteria. Appl. Sci. 2021, 11, 2233. https://doi.org/10.3390/ app11052233

Academic Editor: Stefano Castiglione

Received: 31 January 2021

Accepted: 24 February 2021

Published: 3 March 2021

Publisher's Note: MDPI stays neutral with regard to jurisdictional claims in published maps and institutional affiliations.

Copyright: (c) 2021 by the authors Licensee MDPI, Basel, Switzerland. This article is an open access article distributed under the terms and conditions of the Creative Commons Attribution (CC BY) license (https:/ / creativecommons.org/licenses/by/ $4.0 /)$.
Featured Application: This research provides knowledge into the taxonomic and functional diversity of cultivable bacteria associated with the halophyte Salicornia ramosissima in different types of soil, which need to be considered for the development of rhizosphere engineering technology for the salt tolerant sustainable crops in different environments.

Abstract: Root-associated microbial communities play important roles in the process of adaptation of plant hosts to environment stressors, and in this perspective, the microbiome of halophytes represents a valuable model for understanding the contribution of microorganisms to plant tolerance to salt. Although considered as the most promising halophyte candidate to crop cultivation, Salicornia ramosissima is one of the least-studied species in terms of microbiome composition and the effect of sediment properties on the diversity of plant-growth promoting bacteria associated with the roots. In this work, we aimed at isolating and characterizing halotolerant bacteria associated with the rhizosphere and root tissues of S. ramosissima, envisaging their application in saline agriculture. Endophytic and rhizosphere bacteria were isolated from wild and crop cultivated plants, growing in different estuarine conditions. Isolates were identified based on 16S rRNA sequences and screened for plant-growth promotion traits. The subsets of isolates from different sampling sites were very different in terms of composition but consistent in terms of the plant-growth promoting traits represented. Bacillus was the most represented genus and expressed the wider range of extracellular enzymatic activities. Halotolerant strains of Salinicola, Pseudomonas, Oceanobacillus, Halomonas, Providencia, Bacillus, Psychrobacter and Brevibacterium also exhibited several plant-growth promotion traits (e.g., 3-indole acetic acid (IAA), 1-aminocyclopropane-1-carboxylic acid (ACC) deaminase, siderophores, phosphate solubilization). Considering the taxonomic diversity and the plant-growth promotion potential of the isolates, the collection represents a valuable resource that can be used to optimize the crop cultivation of Salicornia under different environmental conditions and for the attenuation of salt stress in non-halophytes, considering the global threat of arable soil salinization.

Keywords: halophytes; phytobiome; rhizosphere; endophytic bacteria; saline stress

\section{Introduction}

Soil salinity is an environmental problem that challenges agriculture worldwide by imposing the threat of reduced crop productivity [1]. Some plants, designated as halophytes, are adapted to grow and complete their life cycle in saline soils or sediments, These plants are able to grow and reproduce under salinities $>200 \mathrm{mM} \mathrm{NaCl}$ [2], whereas most non-halophytes can withstand moderate salinities but begin to express stress signals at salinities higher than $80 \mathrm{mM}$ of $\mathrm{NaCl}$ [3]. The association with microorganisms has been proven as directly and/or indirectly involved in the improvement of plant growth, 
nutrition and development, and in the overall adaption of halophytes to saline stress [4-8]. Bacterial communities living in the vicinity of plant roots (rhizosphere) and establishing positive interactions with host plants are known as plant-growth promoting rhizobacteria (PGPR). Activities of PGPR in general contribute to a more efficient acquisition of nutrients by the plant through nitrogen fixation activity, increased availability of minerals (phosphate solubilization) or production of siderophores (iron acquisition). In halophytes, rhizobacteria increase the tolerance of plants growing in saline soils by regulating the concentration of ethylene, via the enzyme ACC deaminase and the production of bacterial metabolites that act as phyto-hormones (e.g., IAA (3-indole acetic acid), ABA (abscisic acid), GA3 (gibberellic acid)) [9]. In comparison with rhizobacteria, bacteria colonizing root plant tissues, known as endophytes, establish direct interactions with plant cells and have shown to stimulate plant growth and/or natural resistance to stress in the same way as rhizobacteria [10,11].

Salicornia ramosissima J. Woods is an annual halophyte of the Chenopodiaceae family, widely distributed in salt marshes of the Iberian Peninsula, Northwest Africa [12,13] and the Mediterranean European coast [14,15]. S. ramosissima and the S. europaea aggregate in which S. ramosissima is included [16] have been gaining economic value as gourmet food products, fodder for animals, oil seeds and raw material for the extraction of dietary fiber and high added-value metabolites [17-20]. However, information on the microbiome of $S$. ramosissima and is still relatively scarce in comparison to other halophytes. Cultureindependent analyses indicate that there are significant differences in the structure of bacterial communities associated with different organs and that, in general, diversity is higher in the rhizosphere than among root endophytes [21] and higher in roots than in shoot tissues [22]. Another interesting trait is that the fine structure of these communities is distinctively imprinted by sediment properties [22], particularly salinity [23].

Culture-dependent approaches directed to Salicornia species provide PGPR that effectively attenuates saline stress effects in halophytes [24-27] and non-halophyte crops [28,29]. Halotolerant Proteobacteria (Pseudomonas, Variovorax, Xanthomonas), Firmicutes (Bacillus, Planococcus, Staphylococcus) and Actinobacteria (Arthrobacter, Curtobacterium, Microbacterium) exhibiting plant-growth promoting traits have been retrieved from the endosphere or rhizosphere of S. ramosissima (or S. europaea) $[24,25,28-30]$. However, there is evidence that salinity may impose a strong intraspecific variability on the composition and structure of root-associated plant-growth promoting bacterial guilds, like diazotrophs [30]. Information on the relation between salinity and other sediment properties and the diversity of plant-growth promoting isolates associated with S. ramosissima is scarce. This knowledge would not only expand our understanding of the contribution of particular root-associated bacterial taxa to the adaptation of the $S$. ramosissima to stress but would also support the tailored design of PGPR consortia to be applied in defined plant hosts and in particular environmental contexts.

The objective of this work was to gather evidence of the effect of sediment geochemistry on communities of PGPR associated with S. ramosissima. For this purpose, a collection of halotolerant isolates obtained from the rhizosphere and root endosphere of S. ramosissima populations in three different salt-marsh ecosystems in Portugal was identified and characterized in terms of plant-growth promoting traits. The composition and plant-growth promotion potential of different subsets of isolates was related with the physico-chemical properties of the sediments in order to identify system-specific imprints in root microbiomes, as depicted by a culture-dependent approach.

\section{Materials and Methods}

\subsection{Sampling Sites}

Plants and rhizosphere sediments were collected from three estuarine systems in Portugal: Ria de Aveiro (Av) and Tagus estuary (Tg) on the west coast and Almargem (Al) on the south coast of Algarve (Appendix A, Figure A1). At Ria de Aveiro, samples were obtained from 3 sites, representing different environmental conditions: Av1 corresponds to an intensive crop field of $S$. ramosissima, established at a former salt pan and operated 
by a private company (Horta dos Peixinhos); Av2 corresponds to active salt pans where S. ramosissima grows spontaneously on the elevated borders of the tanks (Santiago da Fonte); Av3 corresponds to a natural salt marsh in a low-salinity section of the estuarine system (Boco), where different halophyte species are represented. For chemical analyses, bulk sediments adjacent to the plants were collected with a hand spade, transferred to sterile plastic bags, transported to the laboratory in cooled boxes and stored at $4{ }^{\circ} \mathrm{C}$ until analyses. Interstitial (pore) water was collected at the corresponding sites using Rhizon samplers (Rhizosphere Research Products, Wageningen, The Netherlands).

\subsection{Physico-Chemical Parameters of Sediments and Pore Water}

Sediment samples were oven-dried at $45^{\circ} \mathrm{C}$ to remove residual moisture. Dry sediments were disaggregated and sieved, and the $<2 \mathrm{~mm}$ fraction was used for further analyses. Sediment organic matter (SOM) content was estimated using loss-on-ignition (LOI). The SOM percent was calculated using the following equation: $\mathrm{SOM}=($ (sediment weight after combustion - oven-dry sediment weight)/oven-dry sediment weight) $\times 100$ [31]

The $\mathrm{pH}$ of sediments was determined both in water and in $\mathrm{CaCl}_{2}$ suspensions $(0.01 \mathrm{M})$, based on the ISO 103090/2005 (ISO 2005) method. For sediments, the relation between mass and volume of suspension was 1:5 (5 g of sediment and $25 \mathrm{~mL}$ of water or $\mathrm{CaCl}_{2}$ solution). The suspensions were stirred for $10 \mathrm{~min}$ and then left resting for $24 \mathrm{~h}$. The measurement was conducted with a glass electrode and $\mathrm{pH}$ meter (Hanna HI 9025). To determine the electric conductivity (EC), a mixture of 1:2 (10 g of sediment and $20 \mathrm{~mL}$ of water) was prepared and stirred for $1 \mathrm{~min}$. The mixture was left resting for $1 \mathrm{~h}$ before measurements were made (Hanna Instruments HI 9033 Conductivity Meter). The $\mathrm{pH}$ and electrical conductivity of pore water were determined directly in $30-40 \mathrm{~mL}$ aliquots. The exchangeable cations sodium $\left(\mathrm{Na}^{+}\right)$, calcium $\left(\mathrm{Ca}^{+2}\right)$, magnesium $\left(\mathrm{Mg}^{+2}\right)$ and potassium $\left(\mathrm{K}^{+}\right)$were determined in ammonia acetate $(1 \mathrm{M} ; \mathrm{pH}=7)$ sediment extracts using inductively coupled plasmamass spectrometry (ICP-MS). Sodium absorption ratio (SAR) and exchangeable sodium percentage (ESP) were determined following the guideline for salinity assessment from the Joint FAO/IAEA (Food and Agriculture Organization/International Atomic Energy Agency) Program [32]. The EC of sediment saturation extract (ECe) was derived from EC values, using the conversion factor described in Sonmez et al. [33] for Turkey clay soil. Precision was estimated by the relative standard deviation (RSD) of triplicate samples and was $\leq 10 \%$.

\subsection{Isolation of Halotolerant Rhizosphere and Endophytic Root Bacteria}

Microorganisms were isolated from plant root tissues (endosphere) and from sediments directly contacting the roots (rhizosphere).

For the isolation of rhizosphere bacteria, freshly harvested S. ramosissima specimens were manually shaken to remove loose sediment particles (bulk sediments). A pool of plant roots with attached sediments $(10 \mathrm{~g})$ was separated from the aboveground plant biomass, transferred to $50 \mathrm{~mL}$ falcon tubes containing $35 \mathrm{~mL}$ of sterile phosphate-buffered saline buffer (PBS) supplemented with $0.01 \%$ Tween 80 and vortexed for $5 \mathrm{~min}$ [34]. The roots were removed, and the suspension was serially diluted in ringer solution and pour-platted in Tryptic Soy Agar (TSA; Liofilchem, Roseto degli Abruzzi) supplemented with $2.5 \% \mathrm{NaCl}$ $(0.4 \mathrm{mM})$ in order to select for halotolerant bacteria [35]. For the isolation of endophytic bacteria, roots were washed with sterile PBS and surface sterilized by immersion in 15\% hydrogen peroxide $\left(\mathrm{H}_{2} \mathrm{O}_{2}\right)$ for $5 \mathrm{~min}$, under shaking [36]. Roots were rinsed three times with sterile PBS, and $100 \mu \mathrm{L}$ aliquots of the last rinse were pour-platted to confirm the efficiency of sterilization. Disinfected root samples were aseptically dried with sterile filter paper under flow chamber and weighed. Approximately $0.3-0.5 \mathrm{~g}$ of roots were cut into fragments $(\sim 30 \mathrm{~cm})$ and homogenized with mortar and pestle with $10 \mathrm{~mL}$ sterile PBS. One gram of the homogenate was used as a starting sample for the preparation of serial tenfold dilutions in PBS [4], which were pour-plated in TSA supplemented with $2.5 \% \mathrm{NaCl}$. 
Cultures were incubated at $30 \pm 2{ }^{\circ} \mathrm{C}$ for 7 days. Isolated colonies with different macroscopic characteristics were selected for purification in saline TSA. The purity of the cultures was assessed by visual inspection and Gram stain. Stock cultures in Tryptic Soy Broth (TSB; Liofilchem, Roseto degli Abruzzi) were amended with 20\% glycerol $(v / v)$ and stored at $-80^{\circ} \mathrm{C}$.

\subsection{Identification of Endophytic and Rhizosphere Bacterial Strains}

Endophytic and rhizosphere bacterial strains were identified based on 16S rRNA gene sequencing. Genomic DNA was isolated using the Higher Purity ${ }^{\mathrm{TM}}$ Bacterial Genomic DNA isolation kit (Canvax). The 16S ribosomal RNA (rRNA) gene was amplified by PCR using 27F (5'-AGA GTT TGA TCM TGG CTC AG-3') and 1512R (5'-CGG CTA CCT TGT TAC GAC TT-3') [37]. The PCR was performed with the Taq PCR Master Mix (Thermo Scientific, Bioportugal, Portugal). The PCR thermal cycling was conducted with an initial denaturation at $94{ }^{\circ} \mathrm{C}$ for $5 \mathrm{~min}$, followed by 30 cycles of denaturation $\left(94{ }^{\circ} \mathrm{C}\right.$ for $45 \mathrm{~s}$ ), annealing $\left(56^{\circ} \mathrm{C}\right.$ for $\left.45 \mathrm{~s}\right)$ and extension $\left(72^{\circ} \mathrm{C}\right.$ for $\left.1 \mathrm{~min} 30 \mathrm{~s}\right)$. The final extension phase was conducted at $72{ }^{\circ} \mathrm{C}$ for $10 \mathrm{~min}$. Amplification products were sequenced using Primer 27F in a Sanger sequencing process at Eurofins (Germany). The obtained sequences were subjected to chimera removal, alignment and clustering into operational taxonomic units (OTUs), with a distance limit of 0.03 ( $97 \%$ similarity), following the tutorial for $16 \mathrm{~S}$ rRNA data of the unsupervised method, available from the Ribosomal Database Project (RDP) [38]. An OTU table was built with abundances for the five sampled sites. The taxonomic classification of all the isolates as well as for a representative of each OTU was determined based on the best matching $16 \mathrm{~S}$ rRNA gene sequences of reference sequences from the National Centre of Biotechnology Information website (NCBI), using blast against the Reference RNA sequences Database (refseq_rna) [39] and the EzBioCloud server [40]. The nucleotide sequence of the representative sequence of each OTU is available in the Genebank Database under the accession numbers MT981726-MT981766.

\subsection{Salinity Tolerance}

The salt tolerance of bacterial isolates was evaluated as described in [41]. Bacteria were grown in 96-well microtiter plates in TSB supplemented with 25, 50 and $100 \mathrm{~g} \mathrm{~L}^{-1}$ $\mathrm{NaCl}$. Each well was inoculated with a fresh exponential phase culture (OD600 0.7). A well containing non-inoculated medium was used as the control. The cultures were incubated at $30 \pm 2{ }^{\circ} \mathrm{C}$ for 2 days, and growth was assessed by OD600 read in a microplate reader (Multiskan FC, Thermo Scientific, Bioportugal, Portugal). The maximum tolerated concentration was considered to be the highest concentration of $\mathrm{NaCl}$ for which growth was detected [41].

\subsection{Screening for Extracellular Enzymatic Activity}

Isolates (120) were individually screened, in triplicate, for amylolytic, cellulolytic and proteolytic activity using solid medium (TSA) amended with the corresponding substrates: $0.2 \%$ starch (Unilever, Viladecans, Spain), 0.5\% carboxymethyl cellulose (SigmaAldrich, St. Louis, MO, USA), 1\% skim milk (Nestlé, Linda-a-Velha, Portugal). For the assessment of lipolytic activity, TSA was cooled to $60^{\circ} \mathrm{C}$ after autoclaving, amended with pure olive oil $(2.5 \% \mathrm{wt} / \mathrm{vol})$ and $10 \mathrm{~mL}$ of a $0.001 \%(\mathrm{wt} / \mathrm{vol})$ filter-sterilized solution of Rhodamine B (Sigma-Aldrich, St. Louis, MO, USA) and vigorously stirred for $1 \mathrm{~min}$ [42]. The medium was allowed to stand for $10 \mathrm{~min}$ at $50{ }^{\circ} \mathrm{C}$ to reduce foaming before it was poured into petri plates. For the assessment of chitinase activity, the isolates were inoculated in solid minimal medium containing $\mathrm{K}_{2} \mathrm{HPO}_{4}\left(0.8 \mathrm{~g} \mathrm{~L}^{-1}\right), \mathrm{KH}_{2} \mathrm{PO}_{4}\left(0.2 \mathrm{~g} \mathrm{~L}^{-1}\right),\left(\mathrm{NH}_{4}\right)_{2} \mathrm{SO}_{4}$ $\left(0.5 \mathrm{~g} \mathrm{~L}^{-1}\right), \mathrm{MgSO}_{4} \cdot 7 \mathrm{H}_{2} \mathrm{O}\left(0.2 \mathrm{~g} \mathrm{~L}^{-1}\right), \mathrm{CaCl}_{2} \cdot 2 \mathrm{H}_{2} \mathrm{O}\left(10 \mathrm{mg} \mathrm{L}^{-1}\right), \mathrm{FeCl}_{3} \cdot 6 \mathrm{H}_{2} \mathrm{O}\left(10 \mathrm{mg} \mathrm{L}^{-1}\right)$, $\mathrm{ZnSO}_{4} \cdot 7 \mathrm{H}_{2} \mathrm{O}\left(1 \mathrm{mg} \mathrm{L}^{-1}\right)$, Casamino acids $\left(2 \mathrm{~g} \mathrm{~L}^{-1}\right)$, purified agar $\left(15 \mathrm{~g} \mathrm{~L}^{-1}\right)$ and an equal volume of a $1 \%(\mathrm{w} / \mathrm{v})$ colloidal chitin suspension prepared from commercial powdered chitin (Sigma-Aldrich, St. Louis, MO, USA) [43]. 
Cultures were incubated for $24-48 \mathrm{~h}$ at $30 \pm 2{ }^{\circ} \mathrm{C}$. Proteolytic and chitinolytic activities were revealed by visualization of a clear halo against an opaque background. Amylolytic and cellulolytic activities were revealed upon addition of Lugol solution to the culture plate. Lipase production was detected as an orange fluorescent halo around colonies, visualized under UV light.

\subsection{Screening for Other Plant-Growth Promoting Traits}

The production of IAA was analyzed colorimetrically [44]. In brief, $70 \mu \mathrm{L}$ of supernatant obtained from cultures grown in TSB supplemented with 1\% L-tryptophan (Alfa Aesar, Karlsruhe, Germany) was mixed with $140 \mu \mathrm{L}$ of Salper solution (2 $\mathrm{mL} 0.5 \mathrm{M} \mathrm{FeCl}_{3}$ in $98 \mathrm{~mL}$ of $35 \% \mathrm{HCLO} 4$ ) in microplate wells (4 replicates). The mixture was incubated in the dark for $30 \mathrm{~min}$ for color development, and OD535 was determined. Standard solutions of commercial IAA (Loba Chemie Pvt, Ltd.) were used to construct a calibration curve for the interpolation of results. An environmental strain of Pseudomonas aeruginosa [45] was included as positive control.

ACC-deaminase activity was determined as the ability to use ACC as a sole nitrogen source with production of $\alpha$-ketobutyrate. Isolates grew in DF (Dworkin and Foster) minimal salt medium, containing $\mathrm{KH}_{2} \mathrm{PO}_{4}\left(4 \mathrm{~g} \mathrm{~L}^{-1}\right), \mathrm{Na}_{2} \mathrm{HPO}_{4}\left(6 \mathrm{~g} \mathrm{~L}^{-1}\right), \mathrm{MgSO}_{4} \cdot 7 \mathrm{H}_{2} \mathrm{O}$ $\left(0.2 \mathrm{~g} \mathrm{~L}^{-1}\right)$, glucose $\left(2 \mathrm{~g} \mathrm{~L}^{-1}\right), \mathrm{FeSO}_{4} \cdot 7 \mathrm{H}_{2} \mathrm{O}\left(1 \mathrm{mg} \mathrm{L}^{-1}\right), \mathrm{H}_{3} \mathrm{BO}_{3}\left(10 \mu \mathrm{g} \mathrm{L}^{-1}\right), \mathrm{MnSO}_{4}$ $\left(10 \mu \mathrm{g} \mathrm{L}^{-1}\right), \mathrm{ZnSO}_{4}\left(70 \mu \mathrm{g} \mathrm{L}^{-1}\right), \mathrm{CuSO}_{4}\left(50 \mu \mathrm{g} \mathrm{L}^{-1}\right), \mathrm{MoO}_{3}\left(10 \mu \mathrm{g} \mathrm{L}^{-1}\right)$, and $\operatorname{agar}\left(15 \mathrm{~g} \mathrm{~L}^{-1}\right)$, with $\mathrm{pH}$ 7.2. This medium was supplemented with either $\left(\mathrm{NH}_{4}\right)_{2} \mathrm{SO}_{4}\left(2 \mathrm{~g} \mathrm{~L}^{-1}\right)$ or $3 \mathrm{mM}$ ACC (Alfa Aesar, Karlsruhe, Germany) or received no supplementation. Overnight cultures in DF supplemented with $\left(\mathrm{NH}_{4}\right)_{2} \mathrm{SO}_{4}$ were spotted on DF minimal salts agar, nonsupplemented or supplemented either nitrogen sources to determine presumptive positive isolates. Cultures were incubated at $30 \pm 2{ }^{\circ} \mathrm{C}$ for 3 days, and growth was checked daily for detection of ACC deaminase activity. A colorimetrical method, using cultures grown in liquid DF medium supplemented with $3 \mathrm{mM} \mathrm{ACC}$, was used for the quantitative analyses of ACC deaminase activity, expressed as the amount of $\alpha$-ketobutyrate produced [46,47]. The OD540 of a sample was compared with that of a standard curve constructed with 0.1 to $1.0 \mathrm{mmol}$ solutions of alpha-ketobutyrate (Sigma-Aldrich, St. Louis, MO, USA). DF medium without supplementation was used as negative control. For each test, 3 replicates were used.

Siderophore production was detected in TSA, deferrated by the addition of $50 \mu \mathrm{M} 2-$ 2 'dipyridil [48]. After incubation, the plates displaying bacterial growth were overlaid with Chrome Azurol S reagent (CAS, MB Biomedicals, LLC) and incubated for $2 \mathrm{~h}$. Siderophore production was detected as a change of color of the overlay from blue to orange, yellow or purple [49]. The test was conducted in triplicate.

Phosphate solubilization was detected by cultivation in SRSM1 broth [50]. Presumptive phosphate solubilization was inferred from the change of color of the medium from purple to yellow, as the result of acidification. Positive results were confirmed by development of a clear halo formed around colonies in Pikovskaya medium, after $24 \mathrm{~h}$ incubation at $30^{\circ} \mathrm{C}$. Pseudomonas aeruginosa [51] and Bacillus cereus [52] were used as positive controls. Two independent assays with 3 replicates each were conducted.

For the detection of nitrogen-fixation ability, isolates were inoculated in a semisolid medium containing glucose $\left(10 \mathrm{~g} \mathrm{~L}^{-1}\right)$, malate $\left(10 \mathrm{~g} \mathrm{~L}^{-1}\right), \mathrm{K}_{2} \mathrm{HPO}_{4}\left(1 \mathrm{~g} \mathrm{~L}^{-1}\right)$, $\mathrm{CaCl}_{2}\left(0.1 \mathrm{~g} \mathrm{~L}^{-1}\right), \mathrm{MgSO}_{4} \cdot 7 \mathrm{H}_{2} \mathrm{O}\left(0.2 \mathrm{~g} \mathrm{~L}^{-1}\right), \mathrm{FeSO}_{4} \cdot 7 \mathrm{H}_{2} \mathrm{O}\left(0.01 \mathrm{~g} \mathrm{~L}^{-1}\right), \mathrm{Na}_{2} \mathrm{MoO}_{4} \cdot 2 \mathrm{H}_{2} \mathrm{O}$ $\left(0.01 \mathrm{~g} \mathrm{~L}^{-1}\right), \mathrm{MnSO}_{4} \cdot 5 \mathrm{H}_{2} \mathrm{O}\left(0.01 \mathrm{~g} \mathrm{~L}^{-1}\right), \mathrm{NaCl}\left(25 \mathrm{~g} \mathrm{~L}^{-1}\right)$, agar $\left(5 \mathrm{~g} \mathrm{~L}^{-1}\right)$ and trace bromothymol blue [53]. Nitrogen fixation was presumptively detected by the change of color of the medium from green to blue. Non-inoculated medium served as a negative control. Each isolate was tested in triplicate.

Exopolysaccharide production, as an indicator of biofilm formation, was assessed by the Crystal violet staining method [54]. Bacterial isolates were grown on TSB on $2 \mathrm{~mL}$ microtubes for $48 \mathrm{~h}$ at $30 \pm 2{ }^{\circ} \mathrm{C}$. After careful washing with Ringer solution, adherent cells were stained with Crystal violet (Atom Scientific) for $5 \mathrm{~min}$. Excess stain was gently 
removed and biofilm was air-dried. Glacial acetic acid 33\% (v/v, Merk, Portugal) was added to resolubilize the dye, and OD570 was determined. Each isolate was tested in 4 replicates. Pseudomonas aeruginosa was used as a positive control [55], and non-inoculated medium as a negative control.

\subsection{Statistics}

The diversity analyses of the 16S rRNA gene sequences of isolates was performed using $\mathrm{R}$ version 4.0.2 [56]. Diversity indices Shannon's $\mathrm{H}^{\prime}$ and Pielou's evenness of OTU abundances were obtained using the vegan package [57] with functions diversity and diversity/log (specnumber), respectively. To compare the variation of OTU composition among the location sites, a dissimilarity matrix was built, based on Bray-Curtis distance, using the OTU abundance table of untransformed data. Non-metric multidimensional scaling (NMDS), based on Bray-Curtis distance, was performed to graphically assess the dissimilarity between the location sites employing the function metaMDS, also in the vegan package. The correlation of sediment characteristics with microbial communities and the sites was determined using envfit of the vegan package [57].

\section{Results}

\subsection{Sediment and Pore Water Characteristics}

The physico-chemical properties of sediment and pore water from the five sampling site locations are summarized in Table 1. Sediment $\mathrm{pH}$ ranged from 6.7 to 8.1, corresponding to neutral sediments ( $\mathrm{pH}$ 6.6-7.3) in Av1, Av3 and Tg, slightly alkaline (pH 7.4-7.8) in Av2 and moderately alkaline ( $\mathrm{pH} 7.9-8.4)$ in $\mathrm{Al}$ [58]. ECe values varied between $39-177 \mathrm{dS} \mathrm{m}^{-1}$, corresponding to saline sediments (ECe $>16 \mathrm{dS} \mathrm{m}^{-1}$ ) [32]. SOM ranged from 2.2-7.22, with the highest values corresponding to Av sites. The concentrations of $\mathrm{Na}\left(385-994 \mathrm{mg} \mathrm{kg}^{-1}\right)$, $\mathrm{Mg}\left(70-355 \mathrm{mg} \mathrm{kg}^{-1}\right)$ and $\mathrm{K}\left(19-84 \mathrm{mg} \mathrm{kg}^{-1}\right)$ were also higher at Av sites than in $\mathrm{Tg}$ or $\mathrm{Al}$ sediments. The concentration of $\mathrm{Ca}\left(84-3016 \mathrm{mg} \mathrm{kg}^{-1}\right)$ was the highest in Al sediments. Together, ECe, ESP, SAR and pH of sediments allowed the characterization of sites Av1 and Av3 as saline-sodic soils and Av2, Tg and Al as non-sodic saline soils [32]. Pore water $\mathrm{pH}$ ranged from 6.8-7, and ECw values (47-128 $\mathrm{dS} \mathrm{m}^{-1}$ ) corresponded to brine [59].

Table 1. Physico-chemical properties of sediments and pore water at Ria de Aveiro (Av), Tagus estuary (Tg) and Almargem (Al) saltmarshes.

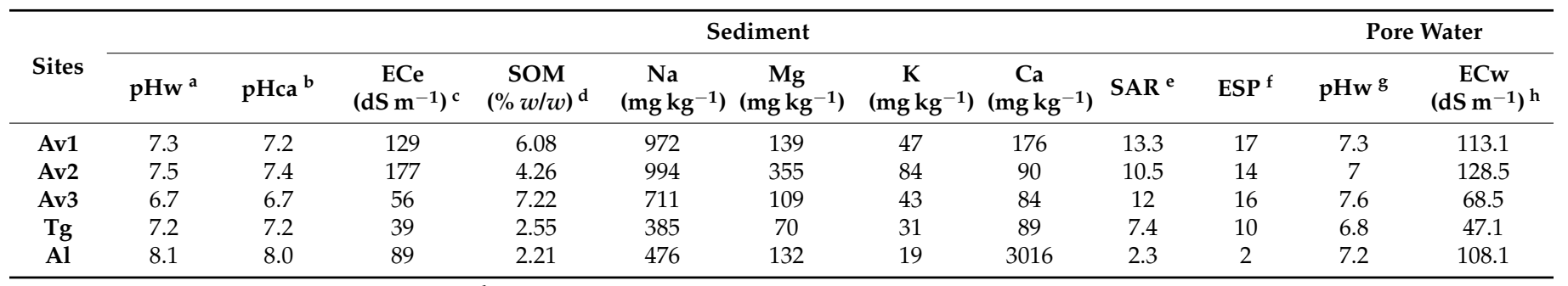

${ }^{\mathrm{a}} \mathrm{pH}$ of sediment in water suspension; ${ }^{\mathrm{b}} \mathrm{pH}$ of sediment in $\mathrm{CaCl}_{2}$ suspension; ${ }^{\mathrm{c}}$ electric conductivity of the sediment saturation extract; ${ }^{\mathrm{d}}$ sediment organic matter; ${ }^{\mathrm{e}}$ sodium adsorption ratio; ${ }^{\mathrm{f}}$ exchangeable sodium percentage; ${ }^{\mathrm{g}}$ pH of pore water; ${ }^{\mathrm{h}}$ electrical conductivity of pore water.

\subsection{Rhizosphere and Endosphere Bacterial Isolates}

In total, 120 salt tolerant bacterial isolates were obtained from the rhizosphere and endosphere of $S$. ramosissima derived from the sampled sites at Portugal's coast. The similarities of 16S rRNA sequences with reference sequences in NCBI ranged from 97 to $100 \%$, allowing the taxonomic assignment of all isolates. Overall, bacteria isolated from the endosphere were more phylogenetically diverse than isolates from the rhizosphere of $S$. ramosissima (Appendix A, Figure A2). This was true for all the sampling sites (Appendix A, Figure A3). The most abundant taxonomic class identified was Bacilli, with the Bacillales order as the most representative for both endosphere and rhizosphere sources. Isolates belonging to Gammaproteobacteria were also common in the rhizosphere and endosphere 
compartments, but members of the Alphaproteobacteria and Actinobacteria taxonomic classes were only recovered from the endosphere (Appendix A, Figure A2). In particular, Bacilli was the only class identified in the rhizosphere of the most saline places (Av2, Av1, Al and $\mathrm{Av} 3$ ), while the rhizosphere of the less saline area ( $\mathrm{Tg}$ ) was more diverse, representing bacteria from three different taxonomic classes. Gammaproteobacteria were represented mainly in the endosphere of all the subsets, except for Al, but also in the rhizosphere of the less saline places (Av3 and Tg). Although in the minority, Actinobacteria were found in the endosphere of all sampling sites, with the exception of Av2 and $\operatorname{Tg}$ (Appendix A, Figure A3). Bacillus was the dominant genus in the total collection (41\%), followed by Staphylococcus (8\%), which, however, was not represented in the subset of isolates from $\mathrm{Tg}$ (Figure 1). Some other halotolerant genera were particularly enriched in specific sites, such as Psychrobacter in Tg, Providencia in Av3 and Halomonas in Av2 (Figure 1).

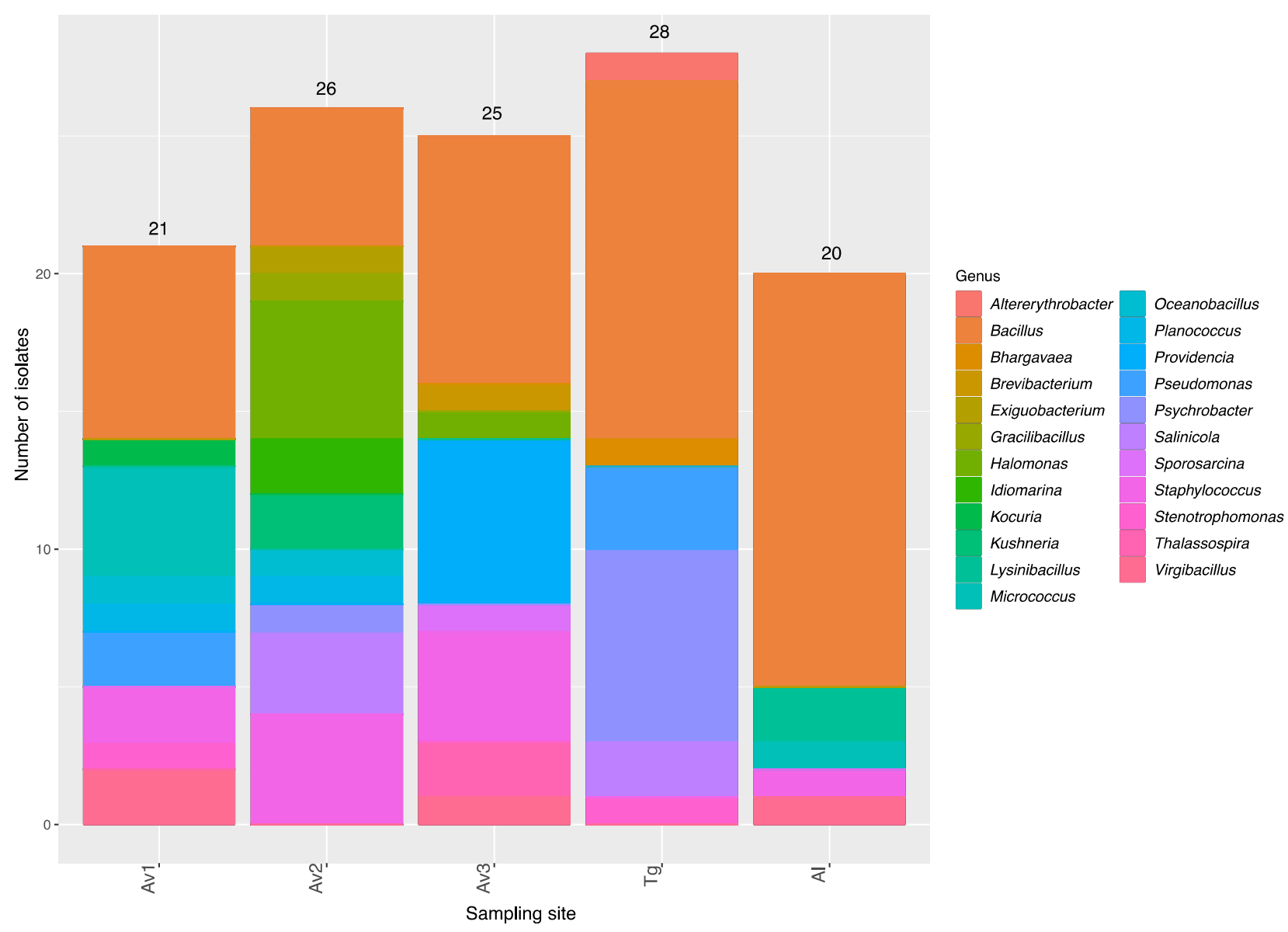

Figure 1. Distribution by genera of the 120 bacterial isolates retrieved from the rhizosphere and root endosphere of Salicornia ramosissima, in the subsets corresponding to 5 sampling sites: Av1, Av2, Av3-Ria de Aveiro; Tg-Tagus estuary; Al-Almargem (Algarve).

The 120 partial $16 \mathrm{~S}$ rRNA sequences (approx. $900 \mathrm{pb}$ ) corresponding to the 120 isolates were aligned and grouped in 41 different OTUs. The resulting OTU table containing the abundance of OTUs across the sampling sites was used to calculate the Shannon diversity and Pielou evenness indices. The highest richness (number of OTUs), evenness and diversity (Shannon) were found for the subset of isolates corresponding to Av1, and the lowest richness, diversity and evenness was found for the Al site (Table 2). 
Table 2. Diversity of the subsets of isolates, based on the analysis of $16 \mathrm{~S}$ rRNA gene partial sequences.

\begin{tabular}{cccccc}
\hline Sites & $\begin{array}{c}\text { Number of } \\
\text { Isolates }\end{array}$ & $\begin{array}{c}\text { Average 16SrRNA } \\
\text { Sequence Length (bp) }\end{array}$ & $\begin{array}{c}\text { Number } \\
\text { of OTUs }\end{array}$ & $\begin{array}{c}\text { Average } \\
\text { Shannon's H' }\end{array}$ & $\begin{array}{c}\text { Average Pielou's } \\
\text { Evenness }\end{array}$ \\
\hline Av1 & 21 & 889 & 17 & 2.71 & 0.95 \\
Av2 & 26 & 884 & 15 & 2.55 & 0.94 \\
Av3 & 25 & 905 & 13 & 2.34 & 0.91 \\
Tg & 28 & 929 & 13 & 2.31 & 0.90 \\
Al & 20 & 940 & 9 & 1.98 & 0.90 \\
\hline
\end{tabular}

a OTU Operational Taxonomic Unit.

Cluster analysis based on a heatmap of OTU abundances (Figure 2) indicated a closer clustering of Av1, $\mathrm{Al}$ and Tg subsets. Although one OTU (OTU 8), identified as Bacillus australimaris, was found in all sampling sites, most of the OTUs were unevenly represented in the different sampling sites, and most of them were restricted to one particular sampling site (Figure 2; Appendix A, Figure A4). Kocuria sp. (OTU 12), Virgibacillus dokdonensis (OTU 22), V. halodenitrificans (OTU 40) and Pseudomonas juntedi (OTU 17) were represented only in the Av1 subset. Genera Exiguobacterium (E. mexicanum; OTU 25), Kushneria (K. phyllosphaerae; OTU 26), Idiomarina (I. loihiensis; OTU 28) Gracibacillus (G. massiliensis; OTU 29), Halomonas titanicae (OTU 27) and B. licheniformis (OTU 36) were represented only in the Av2 subset. Isolates identified as Thalassospira lohafexi (OTU 4), Brevibacterium casei (OTU 6), Providencia rettgeri (OTU 7), Sporosarcina luteola (OTU 11), Bacillus infantis (OTU 41), Bacillus simplex (OTU 37), Halomonas taeanensis (OTU 5) and Staphylococcus xylosus (OTU 9) were found only in the Av3 subset. The species Altererythrobacter indicus (OTU 24) and Bhargavaea ginseng (OTU 34) were found exclusively in site Tg, and OTU 33, identified as Lysinbacillus varians, was exclusive to Al.

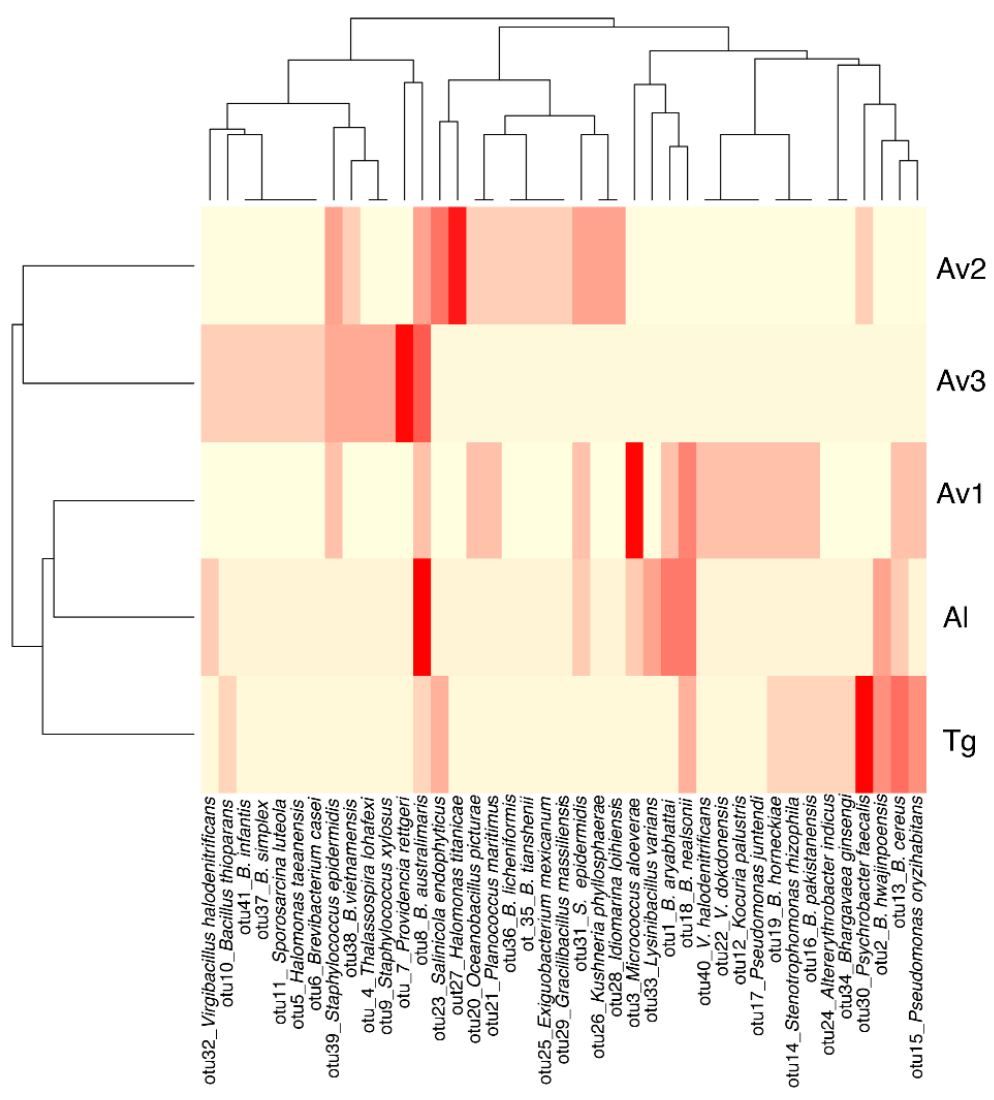

Figure 2. Heatmap showing relative abundance of OTUs in the subsets corresponding to each sampling. Dendrograms show hierarchical clustering between OTUs and sampling sites. 
The ordination analysis relating the composition of the subsets of isolates with the physico-chemical descriptors of sediment and pore water properties in each site is represented in Figure 3. Sediment $\mathrm{pH}$ is related more with the composition of the Av1 and Tg subsets. The $\mathrm{pH}$ of pore water and the concentration of $\mathrm{Ca}^{2+}$ are related with the $\mathrm{Al}$ subset, and SOM is related more with Av3. Descriptors of sediment and pore water salinity (SAR, ESP) and concentration of the cations $\left(\mathrm{Mg}^{2+}, \mathrm{K}^{+}\right.$and $\left.\mathrm{Na}^{+}\right)$are the parameters most related with the composition of the subset of isolates from site Av2.

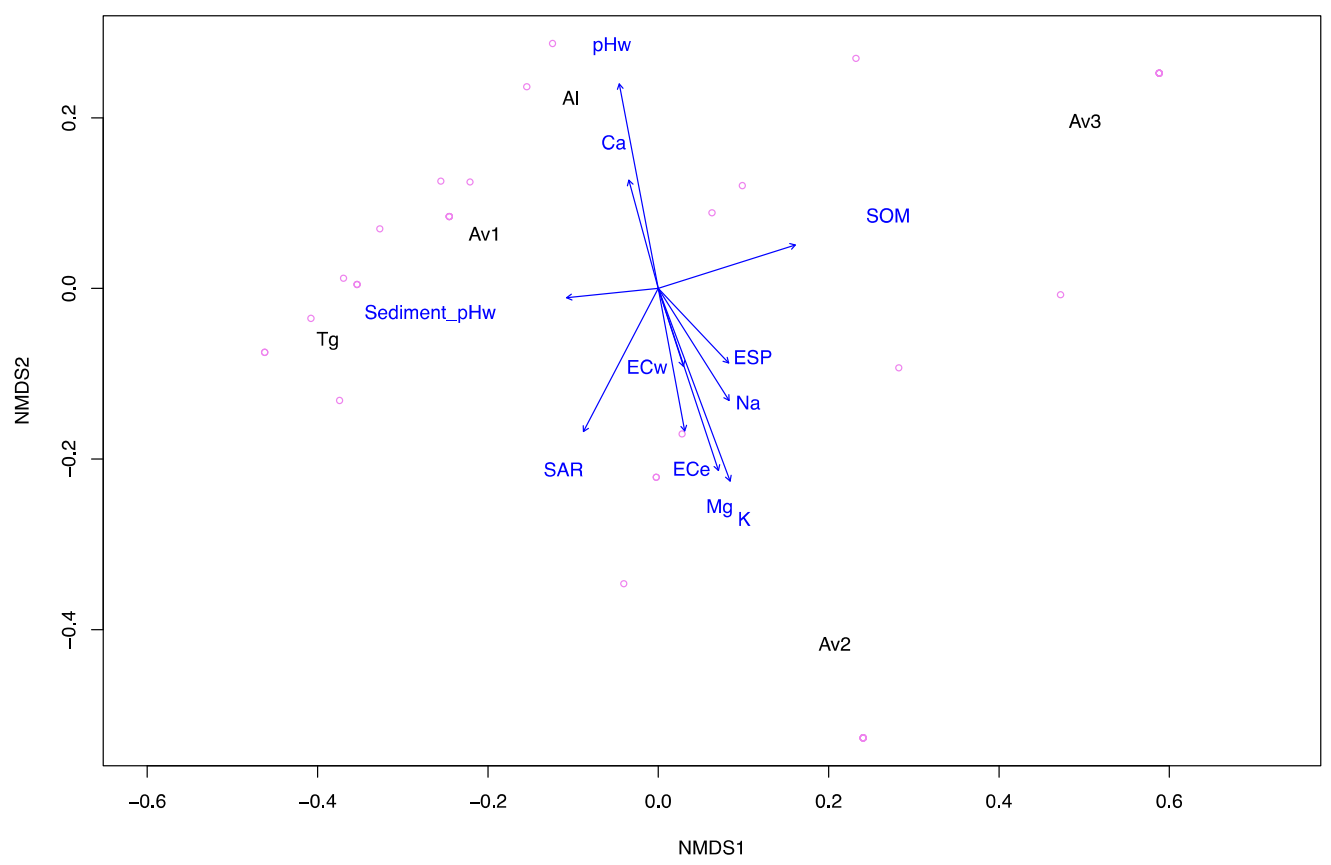

Figure 3. Non-metric multidimensional scaling (NMDS) plot of OTU abundances (violet points) among sampled sites, onto which the sediment parameters Table 1 have been mapped. ECe: electrical conductivity of the sediment saturation extract; ECw: electrical conductivity of pore water; Sediment pHw: $\mathrm{pH}$ of sediment determined in water suspensions; SOM: sediment organic matter content.

\subsection{Salinity Tolerance, Extracellular Enzymatic Activity and Plant-Growth Promoting Traits of} Bacterial Isolates

Most of the isolates (69\%) were able to grow at the highest tested salinity $\left(100 \mathrm{~g} \mathrm{~L}^{-1}\right)$, $28 \%$ tolerated up to $50 \mathrm{~g} \mathrm{~L}^{-1}$ and only $3 \%$ were unable to grow with salinity $>25 \mathrm{~g} \mathrm{~L}^{-1}$ (Figure 4). Isolates growing at the highest salinity were recovered from all the sampling sites; however, the less salt-tolerant isolates (RA2, EA4A, SB78) were found in the lesser saline places (Av3 and Al), except for one isolate (SF91), which was cultivated from the rhizosphere of the saltier local, Av2 (Appendix A, Table A1). Maximum tolerance (growth at $100 \mathrm{~g} \mathrm{~L}^{-1} \mathrm{NaCl}$ ) was found for rhizosphere and endophytic isolates in similar proportion: $46 \%$ and $54 \%$, respectively. The taxonomic identification of the most tolerant isolates was Alphaproteobacteria (genus Thalassospira), Gammaproteobacteria (genera Halomonas, Brevibacterium, Providencia, Kushneria, Salinicola, Idiomarina, Psychrobacter, Pseudomonas), Bacilli (genera Bacillus, Staphylococcus, Exiguobacterium, Oceanobacillus, Lysinibacillus, Planococcus, Virgibacillus, Bhargavaea) and Actinobacteria (genera Micrococcus and Kocuria) (Appendix A, Table A1). 


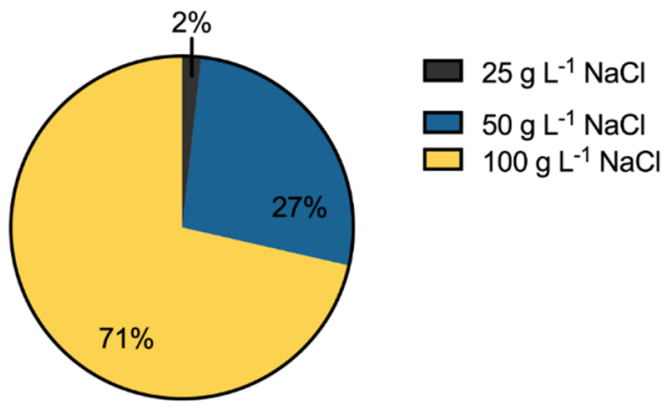

Figure 4. Percent distribution of isolates by levels of salinity tolerance, defined as the maximum concentration of salt $\left(\mathrm{g} \mathrm{L}^{-1} \mathrm{NaCl}\right)$ for which growth was observed.

The profile of extracellular hydrolytic activities (amylase, cellulose, chitinase, lipase, protease) represented in the collection of isolates is depicted in Figure 5. The most common hydrolytic activity was cellulase, detected in 75 isolates $(62.5 \%)$, followed by amylase, protease and lipase, found in $51(42.5 \%), 35(29.2 \%)$ and $32(26.7 \%)$ isolates, respectively. Chitinase activity was the least represented (16 isolates). Only isolates SB4 (Av3), SF59 (Av2) and SB102 (Av3), all rhizospheric bacteria of the genus Bacillus, (Appendix A, Table A1), tested positive for all the enzymes. Forty-three isolates produced at least two different extracellular enzymes, and the association cellulase + amylase was the most frequent (14).

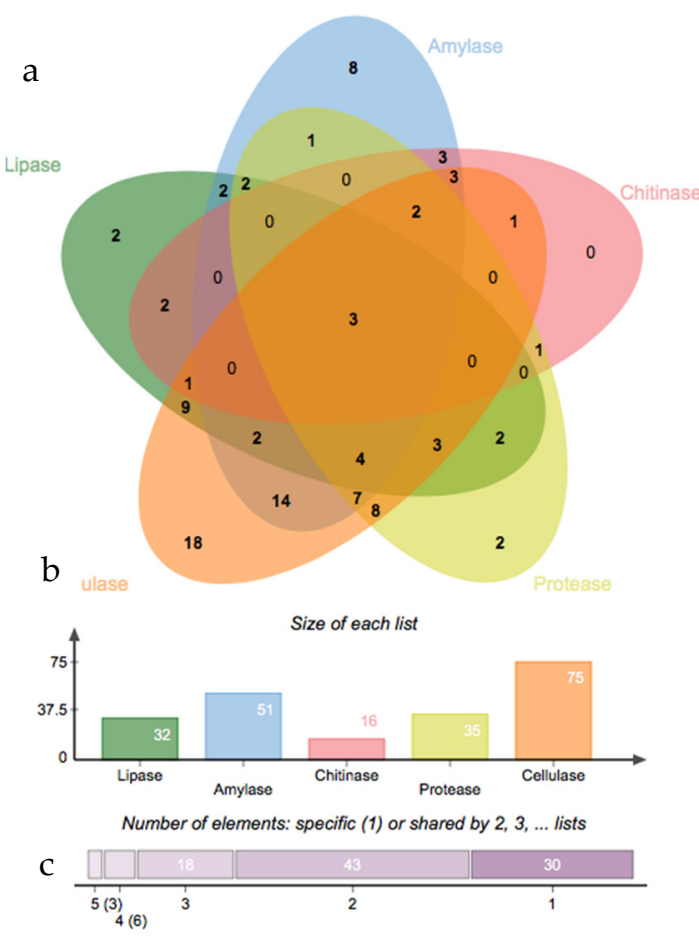

Figure 5. Number of isolates expressing different extracellular enzymatic activities (a); number of isolates expressing each extracellular enzymatic activity (b); number of isolates combining the expression of 1, 2, 3, 4 or 5 different activities (c).

The proportion of enzyme-producing bacteria in each site is shown in Appendix A, Table A2. Isolates from the Al site stand out for proteolytic activity, but were not prolific cellulase, chitinase and amylase producers. Higher production of Chitinase and amylase were detected mainly in Av2 isolates, which in turn were lower protease producers. Av3 isolates produced predominantly lipase and cellulase. Cellulolytic activity was also abundant in isolates from Tg and Av1. Tg isolates were the less frequent lipase producers (Appendix A, Table A2). 
The results of plant-growth promoting traits (siderophores, IAA, EPS (Exopolysaccharides), ACC-deaminase activity, phosphate solubilization or nitrogen fixation) for the collection of 120 isolates is presented in Appendix A, Table A1, and summarized in Figure 6 and Appendix A, Table A2. EPS production (71\%), phosphate solubilization capacity (61\%) and siderophore production (58\%) were well represented in the collection of isolates. Almost half of the isolates collection (45\%) produced interesting levels of IAA. On the contrary, only 5 isolates (4\%) affiliated with Psychrobacter (Rl3), Stenotrophomonas (EH7), Bacillus (ES2), Halomonas (ES10) and Brevibacterium (EB3) genus (Appendix A, Table A1) showed evidence of nitrogen fixation capacity. None of the isolates combined all the tested PGP traits. In contrast, approximately $25 \%$ of the isolates (33) showed activity for only one of the traits. A total of 12 isolates (EL13, RL18, EH2, ES4, ES14, EB7, EB39, EB40, EB41B, RA9, RA33 and SF91), affiliated with genera Salinicola, Pseudomonas, Oceanobacillus, Halomonas, Providencia, Bacillus, Kocuria and Staphylococcus, shared four PGP activities: phosphate solubilization, production of siderophores, production of IAA and ACC-deaminase activity. In addition, 2 isolates with nitrogen-fixation capacity, identified as Psychrobacter (RL3) and Brevibacterium (EB3) (Appendix A, Table A1), also produced siderophores and IAA and expressed ACC-deaminase activity.

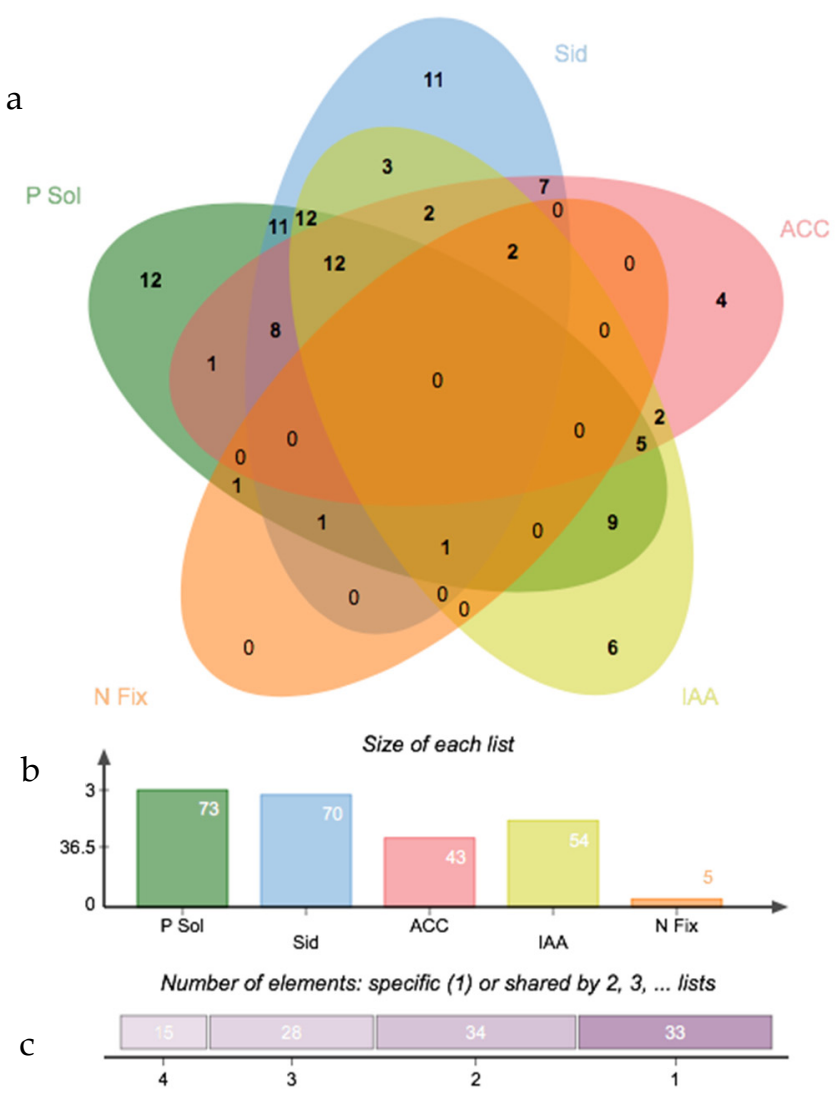

Figure 6. Number of isolates expressing different plant-growth promoting traits (a); number of isolates displaying each plant-growth promoting trait (b); number of isolates combining the expression of $1,2,3,4,5$ or 6 plant-growth promoting traits (c).

Considering the plant-growth promotion trait expression by site (Appendix A, Table A2), EPS production was especially frequent in isolates from Av1, $\mathrm{Al}$ and Av2, as more than $80 \%$ of the isolates were able to form biofilms. Higher IAA production (62\%) and Psolubilization (67\%) was detected in isolates from Av1. Siderophore production, on the other hand, was more frequent $(72 \%)$ in isolates from Av3. ACC-deaminase activity was by far the greater $(75 \%)$ in Tg isolates. As for Nitrogen fixation, it was detected in at least one isolate in each site, except for two isolates in $\mathrm{Av} 2$ and no $\mathrm{N}$ fixation ability in the $\mathrm{Al}$ site. 


\section{Discussions}

Plant-associated microbial communities, and especially halotolerant PGPB (Plant Growth-Promoting Bacteria), contribute to the adaptation of the hosts to the dynamic and challenging conditions of coastal salt marsh ecosystems [1,60]. It is also well known that plant species and sediment properties interact in shaping the composition and structure of rhizosphere and root microbiomes [57,58]. This work intended to address the hypothesis that the effect of sediment properties also imprints the diversity of PGP isolates and the prevailing PGP mechanisms in different populations of the same species. The halophyte S. ramosissima, very well represented in European salt marshes, was chosen as the model species. The rhizosphere and root endosphere microbiomes of plants growing in five distinct salt marshes were screened for PGP bacteria. The composition and PGP potential of the subsets of isolates from each site were analyzed in relation to the physico-chemical descriptors of sediment and pore water.

Sediments of the five sampling sites were all strongly saline (Table 1) but differed greatly in their salinity levels, $\mathrm{pH}$, sodium-related parameters like SAR and ESP, concentration of exchangeable cations and organic matter content (Table 1). Although soil salinity has been shown to decrease bacterial diversity in rhizospheres [61], in this study, the greater diversity of culturable halotolerant bacteria associated with the roots of S. ramosissima was observed in the most saline sediments of Ria de Aveiro saltmarshes (Av1 and Av2). The lowest diversity was found in the subset of isolates retrieved from the southernmost site (Al), on the southern Atlantic coast (Algarve), where the salinity indicators were the lowest. The plants collected from this site already had their color changed from green to red, indicating that they were either experiencing abiotic stress or senescence. This could explain the lower taxonomic diversity of the cultivable bacterial community found at this site. Salinity, however, seems to be neither the sole nor even the most relevant determinant of the diversity of isolated halotolerant bacteria. NMDS analysis (Figure 3) indicates that the composition of the subsets of PGP bacteria corresponding to different salt marshes within the same estuarine system (Ria de Aveiro) was related also to different sediment parameters. Neutral $\mathrm{pH}$ is more strongly related to the composition of Av1 and $\mathrm{Tg}$ subsets. The overall concentration of exchangeable cations and the parameters determined for soil sodicity (SAR and ESP) seemed to influence the bacterial composition in Av2, and the higher content of organic matter determined bacterial diversity in Av3. As a consequence of the effect of different sediment properties, there was a significant variability in the composition of the sets of isolates obtained from plants growing in different sites. In fact, the structure of the subset of isolates from site Av1 was more similar to the subset corresponding to geographically distant saltmarshes ( $\mathrm{Al}$ and $\mathrm{Tg}$ ) than to the other two sites of the estuarine system of Ria de Aveiro (Figure 2; Appendix A, Figure A1), which confirms that site-specific factors related to sediment properties may have a major impact on the outcome of the culture-dependent approaches used to prospect the microbiome of halophyte species for bacteria with PGP potential.

The identification at the phylum level revealed the overall dominance of Firmicutes in the collection of isolates, followed by Proteobacteria and Actinobacteria. These results are in line with reports of culture-dependent analyses of the root microbiomes of other species of Salicornia included in the S. europaea aggregate [36]. However, cultivable bacteria are estimated to represent only $0.01-1 \%$ of the total microbial species present in a given environment $[21,23,62]$. Despite this, culture-independent approaches, as performed by [21], contribute to better resolution of the bacterial communities associated with plants. However, the culture-dependent studies allow access to the metabolic capabilities of bacterial communities, which is later useful in testing their activity in host-microbiota interactions. From the total of the 110 families reported by [21], in our study we shared in common nine of these families and were able to recover four other families not detected in [21]: Micrococcaceae, Brevibacteriaceae, Morganellaceae and Lysobacteraceae. Therefore, for the aims of this study, which included the isolation of bacterial communities associated with S. ramosissima to test their potential for PGP, our approach achieved the access to 
bacterial members that would actually be useful for the development of better strategies in sustainable agriculture. Culture-independent approaches indicate that Proteobacteria normally outnumber Firmicutes in the bacterial communities of the roots and in the rhizosphere of Salicornia sp.; other phyla are represented with variable abundances $[21,23]$. The predominance of Firmicutes and Bacilli was more evident in the subset of isolates from both rhizosphere and endosphere of the $\mathrm{Al}$ site (Appendix A, Figure A3), characterized by high sediment $\mathrm{pH}$ and low organic matter content. The capacity to form endospores, highly resistant to unfavorable nutritional conditions, chemical stress and desiccation, may contribute to this enrichment. The highest proportion of Actinobacteria was found in the Av1 endosphere subset (Appendix A, Figure A3), which corresponds to the most saline sediments. Other authors have previously reported the association of Actinobacteria in the endosphere of S. europaea, particularly in plants growing in high salinity sites $[21,23,63]$. The endosphere represents a more stable and sheltered environment for symbiotic bacteria, which may underlie the preference of Actinobacteria for this plant compartment [64]. A possible relation between bacterial diversity and plant origin (wild vs. crop) was eliminated. As shown in Table 2, Av1 (crop site) rendered the highest number of OTUs (17). Four of these OTUs (belonging to genera Kocuria, Virgibacillus, and Pseudomonas) were found exclusively associated with plants from that site. Although Kocuria was only isolated from the Av1 site, Virgibacillus and Pseudomonas were also isolated from $\mathrm{Al}$ and $\mathrm{Tg}$, respectively. All other OTUs present in crop plants were also detected in wild plants from other sites. This was the case for OTUs corresponding to Micrococcus (also in Al), Bacillus (in all other sites), Stenotrophomonas (also in Tg), Pseudomonas (also in Tg) and Oceanobacillus (also in Av3). Therefore, we found no evidence that cultivated plants are different from wild plants in terms of culturable populations represented in the microbiome.

Bulk soil microbial communities were not studied, as it would surpass the scope of this work. However, some studies found that the microbiome of bulk soil was closely related to that of the rhizosphere [65], and that rhizosphere soil was found to contain higher microbial biomass compared to bulk soil [66]. Nevertheless, in a separate study, significant differences were found between rhizosphere and bulk soil microbial composition [67]. As soil is the primary source of microbes inhabiting the rhizosphere, similarities are expected.

The possibility of using rhizosphere and endosphere bacteria as biostimulants for saline agriculture or as saline-stress attenuators for salt-sensitive crops has been the motivation for many culture-dependent analyses of the microbiome of halophyte species. Salinity tolerance is a requirement of PGP bacteria used for the attenuation of saline stress. In the overall collection of isolates, $71 \%$ were able to grow at a salinity corresponding to $100 \mathrm{~g} \mathrm{~L}^{-1} \mathrm{NaCl}$. This result demonstrates the potential of halophyte plant microbiota to harbor bacteria adapted to high salinities [11].

Bacterial extracellular enzymes reflect the spectrum of available polymeric substrates and play relevant roles in the processes of colonization of root tissues and biocontrol of plant pathogens [68]. Cellulase was the most common enzyme, expressed by $62 \%$ of the isolates, followed by amylase, proteases, lipases and chitinase, expressed by $48 \%, 32 \%, 27 \%$ and $13 \%$ of the isolates, respectively. These frequencies are similar to those reported for PGP bacteria isolated from the endosphere of Halimione portucaloides, with the exception of lipolytic activity, which was comparatively less represented in the rhizosphere and root endosphere isolates of S. ramosissima ( $27 \%$ compared to $46 \%$ in H. portulacoides) [69]. The release of cellulase accelerates the process of colonization of plant tissues, and this appears to be crucial for the close interaction between bacteria and plants under stressful environmental conditions [64,65]. Cellulolytic PGP used in agriculture not only improves plant growth but also contributes to the degradation of plant material in soils, improving fertility and also providing a biocontrol effect against plant pathogens [70]. Bacterial cellulase, lipase, protease and chitinase degrade major components of the fungal cell wall [71-73] and therefore contribute to the biocontrol effect of PGP bacteria. Only three isolates, identified as Bacillus australimaris, B. vietnamensis, and B. infantis (Appendix A, Table A1), expressed all enzymes, confirming the potential of Bacilli as biocontrol agents [74]. Approximately one 
third of the isolates expressed two extracellular enzymes. The most frequent combination was cellulase and amylase, indicating a positive selection of the enzymatic capacity to directly interact with plant tissues.

Positive correlation between extracellular enzymatic activity, especially cellulolytic, and sediment properties like organic matter content and conductivity have been reported $[75,76]$. This correlation was also evident in the present study. The frequency of cellulolytic and lipolytic isolates was the highest in the Av1 and AV3 subsets, respectively (Appendix A, Table A2), which corresponds to sediments with high organic matter content and electrical conductivity (Table 1).

The bacterial production of extracellular polymeric substances (EPS) can aid plants in resisting drought and salinity $[77,78]$. EPS-producing bacteria accounted for $72 \%$ of the cultivable isolated bacteria in our study (Appendix A, Tables A1 and A2). The highest frequency of EPS-producing isolates was observed in the most saline sediments and pore waters, AV1 and AV2, accounting for $90 \%$ and $81 \%$ of the isolates, respectively, and $90 \%$ of the isolates in the $\mathrm{Al}$ site were characterized by highly saline pore waters. Salinity can act as a positive environment for EPS, as their production is enhanced in response to osmotic stress [79]. EPS are also involved in the sequestration of minerals [80]. Therefore, EPS production can also be regarded as a PGP trait contributing to plant access to nutrients, in parallel with the expression of siderophores, nitrogen fixation and phosphate solubilization capacities.

Approximately $60 \%$ of the isolates were able to solubilize phosphate or produce siderophores, and 44 isolates ( $37 \%)$, identified as Bacillus aryabhattai, B. australimaris, B. cereus, B. horneckiae, B. hwajinpoensi, B. tianshenii, Halomonas titanicae, Kocuria palustris, Kushneria phyllosphaerae, Micrococcus aloeverae, Oceanobacillus picturae, Providencia rettgeri, Pseudomonas juntendi, P. oryzihabitans, Psychrobacter faecalis, Salinicola endophyticus, Sporosarcina luteola, Staphylococcus epidermidis, S. xylosus and Stenotrophomonas rhizophila, could do both (Appendix A, Table A1). Phosphorus (P) is the least accessible macronutrient for plants due to the propensity to form insoluble complexes with cations, and in saline soils, $P$ is even less available $[75,81,82]$. Phosphate-solubilizing bacteria can improve the uptake of $\mathrm{P}$ by the roots through the production of organic acids [83], and EPS have a synergistic effect by holding free $\mathrm{P}$ in the medium [84]. Siderophores can also enhance $\mathrm{P}$ solubilization by chelating substances that form stable complexes with $P$ adsorbents [85]. This interaction may explain the frequent co-occurrence of EPS and siderophore production and P-solubilization capacities in the collection of isolates.

In turn, $\mathrm{P}$ and $\mathrm{Fe}$ are important for $\mathrm{N}$-fixation because $\mathrm{P}$ is required for energy transfer processes and $\mathrm{Fe}$ is a constituent of nitrogenase and leghaemoglobin [86,87]. However, in halophyte endophytic bacteria this dependence may not be strict. Bacilli represented the majority of the isolates that combined siderophore production with P-solubilization capacity, but N-fixation capacity was not detected in any of them. Only one endosphere isolate (Kushneria phyllosphaerae) accumulated the capacities of phosphate solubilization, siderophore production and nitrogen fixation. N-fixation was detected in a halophilic Kushneria marisflavi strain, isolated from the rhizosphere of Salicornia sp. in hypersaline soils of Tunisia, but that isolate lacked phosphate solubilization capacity [88]. N-fixation was overall less frequent than either P-solubilization or siderophore production and was not represented in one of the subsets of isolates $(\mathrm{Al})$. Nitrogen fixation is energetically costly for bacteria [30] and negatively affected by soil salinity [89,90], which can explain the low number of isolates exhibiting this feature. In Salicornia-dominated areas, cyanobacteria have a very important role in Nitrogen fixation, especially in warmer months and low plant density areas [91]. N-fixing cyanobacteria have been detected in the epiphytic communities associated with halophytes [92,93]. However, our strategy of cultivation and isolation did not allow the detection of these prokaryotes. It also possible that the method we used to screen nitrogen fixation was not fully adequate for our isolates. In addition to these factors, there is the possibility of loss of the ability to express N-fixation genes during successive cultivations in TSA medium. All $\mathrm{N}$-fixing isolates came from the 
endosphere, which represents a more protected environment in comparison to soil or the rhizosphere [64]. Actinobacteria have been found to dominate N-fixing endophytic PGP bacteria in S. euopaea [30]. In this study, only one out of five N-fixing endophytic isolates associated with S. ramosissima belonged to Actinobacteria (EB3, genus Brevibacterium). The majority of the plant-associated N-fixing isolates found in this study were $\gamma$-Proteobacteria (genera Halomonas, Kushneria, Psychrobacter and Stenotrophomonas). The predominance of Gram-negative taxa among N-fixing isolates from saline environments, namely the rhizosphere of Salicornia, has been reported [88].

IAA production and ACC-deaminase are two of the most valued plant-growth promoting traits and are considered as requirements for endophytic and rhizospheric competence [94]. One common effect is the increase in root length, surface area, and root hair density, improving the access to soil nutrients under stress conditions [64,81]. IAA production was detected in 54 isolates (45\%), and six of them produced moderate to high amounts of IAA, ranging from $40 \mu \mathrm{L} \mathrm{mL}^{-1}$ to over $72 \mu \mathrm{L} \mathrm{mL}{ }^{-1}$. In previous studies, $3.6 \%$ of isolated bacteria from Halimione portulacoides produced high amounts if IAA (over $100 \mu \mathrm{L} \mathrm{mL}^{-1}$ ), and bacteria isolated from Mediterranean halophytes produced IAA in the range of $17.92-112.5 \mu \mathrm{g} \mathrm{mL} \mathrm{m}^{-1}[69,95]$. ACC-deaminase activity was slightly less frequent. Some isolates failed to grow and could not be tested, which hindered an accurate estimate of the frequency of this PGP trait. However, approximately $41 \%$ of the isolates were able to cleave ACC, and 25 isolates expressed both ACC-deaminase activity and IAA production. It has been proposed these two traits are biochemically related and may actually counteract in the regulation of ethylene concentrations. Both plant and bacterial ACC-deaminases reduce the concentration of ACC, which is a precursor of ethylene, whereas IAA can enhance ethylene production by stimulating the activity of the ACC synthase in plant tissues [96]. In this case, the activity of ACC deaminase from PGPB would be of the outmost importance to balance ethylene levels in plants facing stress.

With the exception of $\mathrm{N}$-fixation and chitinase activity, which were not detected in isolates from Al, all other PGP traits were represented in each of the subsets (Appendix A, Figure A5). The low organic matter content of Al sediments may explain a poorer spectrum of bacterial extracellular enzymatic activities but not the lack of $\mathrm{N}$-fixing isolates in the Al subset. The abundance of diazotrophs in sediments tends to decrease with increasing salinity $[89,90]$, but Al sediments would be the least stressful in terms of salinity and conductivity. Therefore, their highly saline pore waters (Table 1) or other factors (e.g., moisture, total $\mathrm{N}, \mathrm{C} / \mathrm{N}$ ratio) not covered by the set of physico-chemical parameters may be involved $[97,98]$.

\section{Conclusions}

Overall, a wide spectrum of PGP traits associated with endospheric and rhizospheric competence and direct benefits to the plant host (nutrient supply, detoxification, osmotic protection, attenuation of stress responses, stimulation of growth, inactivation of pathogens) were represented in the collection of isolates. However, the subsets of isolates were very different in terms of composition, indicating that, according to the physico-chemical conditions of each site, the benefits to the same host species are delivered by different bacterial players. This capacity to interact with different bacterial communities may underlie the occurrence of S. ramosissima in a wide diversity of coastal habitats and the capacity of this species to thrive under harsh and unstable environmental conditions.

The rhizosphere and root endosphere of S. ramosissima proved to be a rich seedbank for halotolerant PGPB, several of which displayed multiple PGP traits. Salinicola endophyticus (EL13), Bacillus aryabhattai (SP1016 20) and Pseudomonas oryzihabitans (RL18) were able to produce IAA, siderophores, EPS and to solubilize phosphate. S. endophyticus was the most prolific IAA producer and was an ACC-deaminase producer. P. oryzihabitans was also ACC-deaminase positive. B. aryabhattai expressed all the tested extracellular enzymes. It also produces $\mathrm{HCN}$, inhibits the phytopathogenic fungus Alternaria and increases the germination of $S$. ramosissima seeds at high salinities [26]. These isolates 
are promising candidates in the consortia of PGPB to be used as inoculants for saline or traditional agriculture.

The microbiome of halophytes is still a valuable model for the understanding of the role of bacteria in the host adaptive responses and, in a more applied perspective, as sources of PGPB. However, knowledge on the environmental factors that modulate plant-bacteria relations will be paramount in the transition to the generalized, efficient and sustainable use of PGPB in agriculture, which faces the challenges of soil salinization and climate change.

Author Contributions: Conceptualization, I.N.S.-G., M.J.F. and A.C.; methodology, I.N.S.-G., M.J.F., S.F., P.F. and C.P; validation and formal analysis, I.N.S.-G., M.J.F., C.P. and A.C.; investigation, I.N.S.-G., M.J.F., S.F., P.F. and C.P.; resources, C.P. and A.C.; data curation, I.N.S.-G., M.J.F. and S.F.; writing — original draft preparation, I.N.S.-G., M.J.F. and A.C.; writing-review and editing, I.N.S.-G., M.J.F., C.P. and A.C.; visualization, I.N.S.-G. and M.J.F.; supervision, A.C. and H.S.; project administration, A.C. and H.S.; funding acquisition, A.C. and H.S. All authors have read and agreed to the published version of the manuscript.

Funding: This work was supported by project Rhizomis PTDC/BIA-MIC/29736/2017 financed by Fundação para a Ciência e Tecnologia (FCT) through the Regional Operational Program of the Center (02/SAICT / 2017) with FEDER funds (European Regional Development Fund, FNR and OE) and by FCT through CESAM (UIDP/50017/2020 + UIDB/50017/2020) and Geobiotec (UIDP/04035/2020). We also acknowledge FCT/FSE for the financial support to Maria João Ferreira through a PhD grant (PD/BD/150363/2019).

Institutional Review Board Statement: Not applicable.

Informed Consent Statement: Not applicable.

Data Availability Statement: The nucleotide sequences generated and analyzed in this work are available in the Genebank Database under the accession numbers MT981726-MT981766.

Acknowledgments: We thank Horta dos Peixinhos, Salina Greens, Isabel Caçador (University of Lisbon) and the members of the Centre for Marine and Environmental Research (CIMA, University of Algarve) for their help and support during sampling. We also want to thank Newton Gomes, Antonio Louvado and Vanessa Oliveira from the Laboratory for Molecular Studies of Marine Environments (LEMAM) for their help and infrastructure. Furthermore, we thank the staff and infrastructure of the Laboratory of Applied and Environmental Microbiology (LMAA) and GeoBioTec from the University of Aveiro.

Conflicts of Interest: The authors declare no conflict of interest. The funders had no role in the design of the study; in the collection, analyses, or interpretation of data; in the writing of the manuscript, or in the decision to publish the results. 


\section{Appendix A}
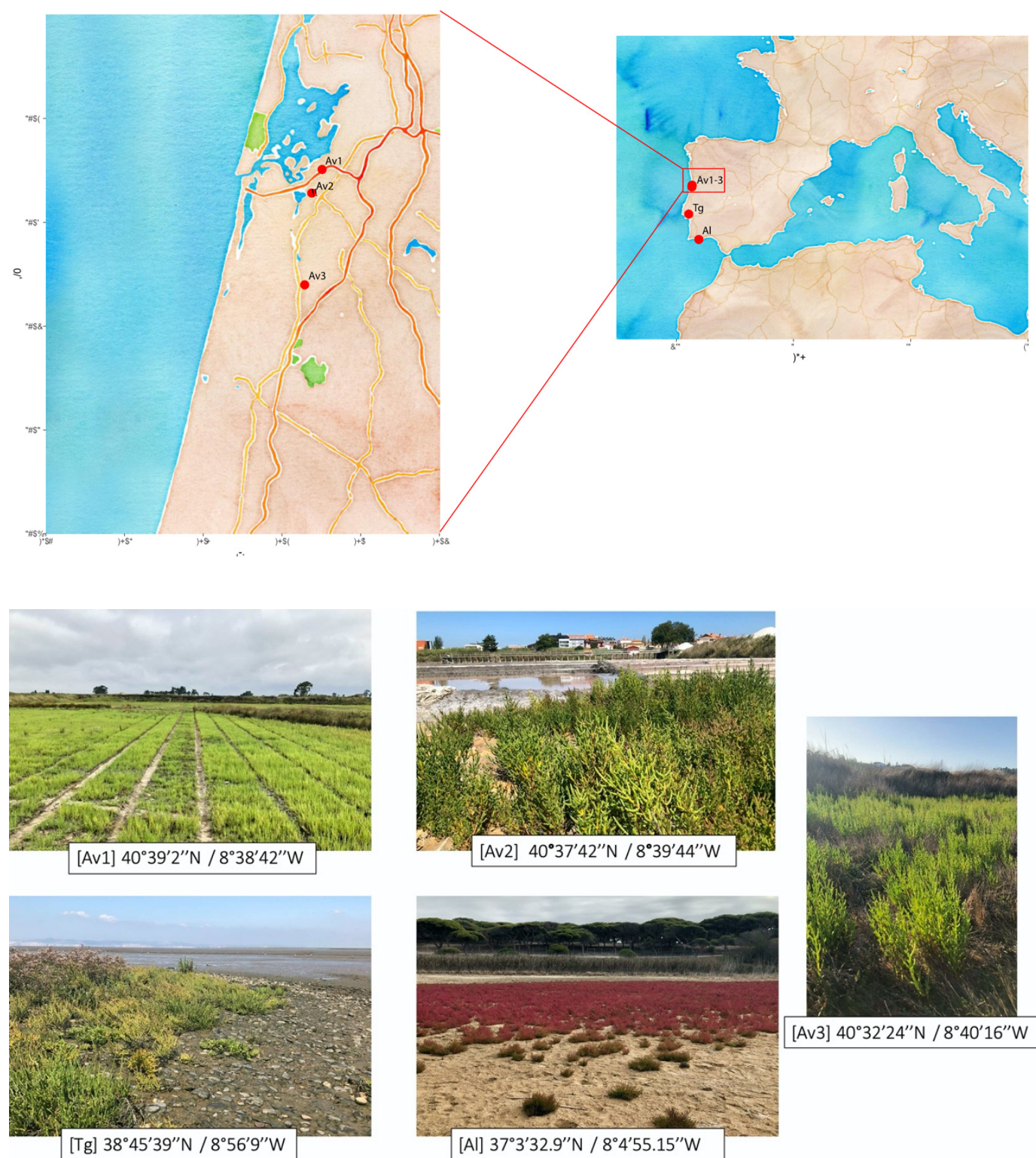

Figure A1. Sampling sites located along the Portugal coast. Locations Av1, Av2, Av3 correspond to three different sites at Ria de Aveiro; Tg and Al correspond to the Tagus estuary and Almargem coast, respectively. 


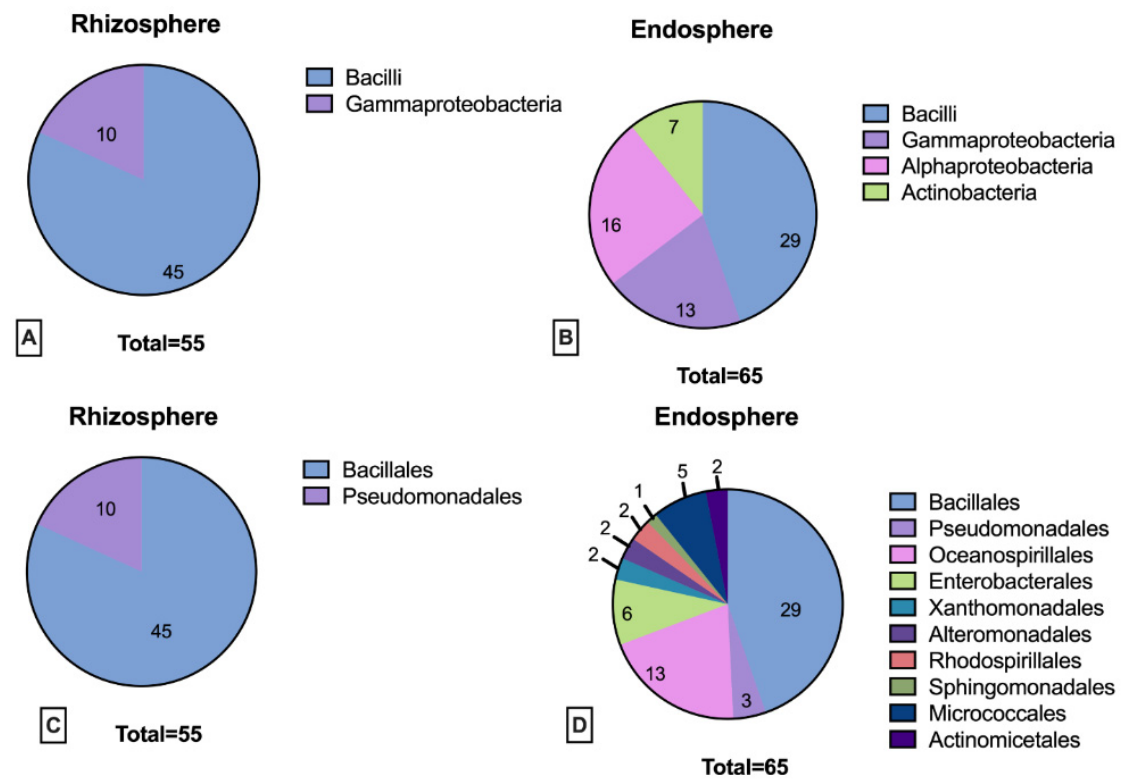

Figure A2. Total taxonomic distribution of the isolates from the endosphere and rhizosphere of Salicornia ramosissima at class $(\mathbf{A}, \mathbf{B})$ and order $(\mathbf{C}, \mathbf{D})$ taxonomic levels.

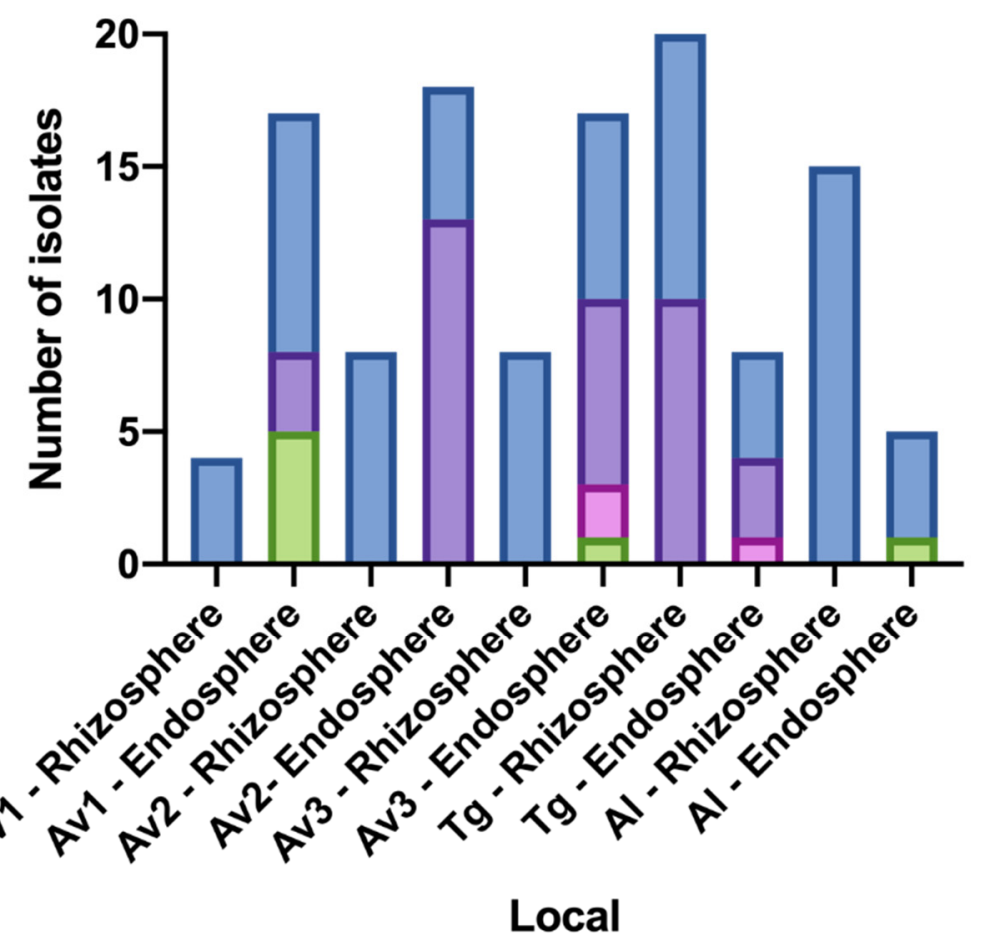

Bacilli

Gammaproteobacteria Alphaproteobacteria Actinobacteria

Figure A3. Distribution of the taxonomic affiliation among the collected sites and isolation source (rhizosphere and endosphere) by class level. 


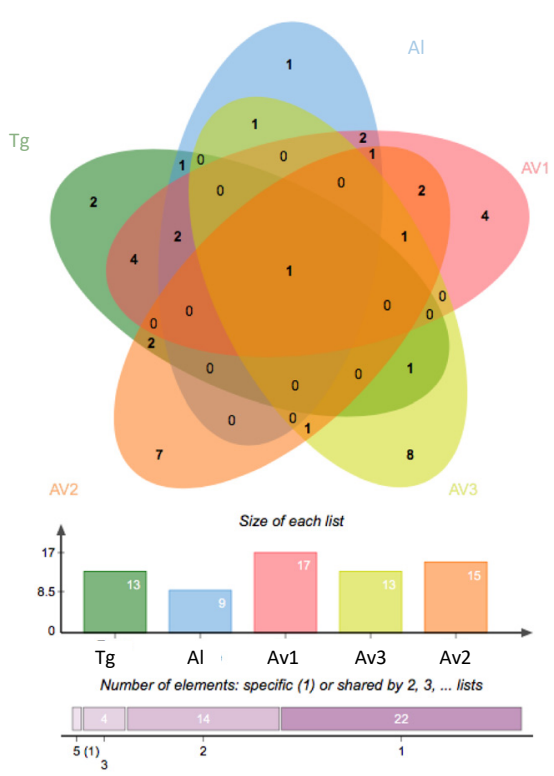

(A)

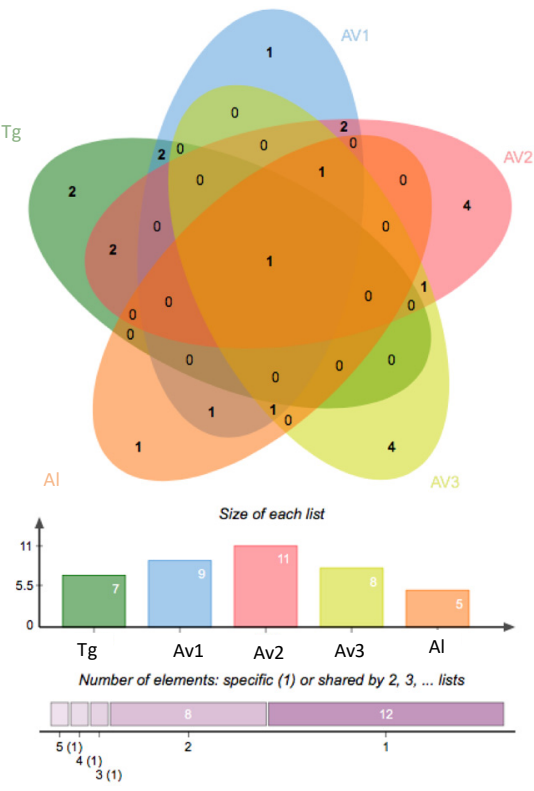

(B)

Figure A4. Venn diagram showing the abundance of isolates in the sampling sites represented by genera (A) and OTU (B).

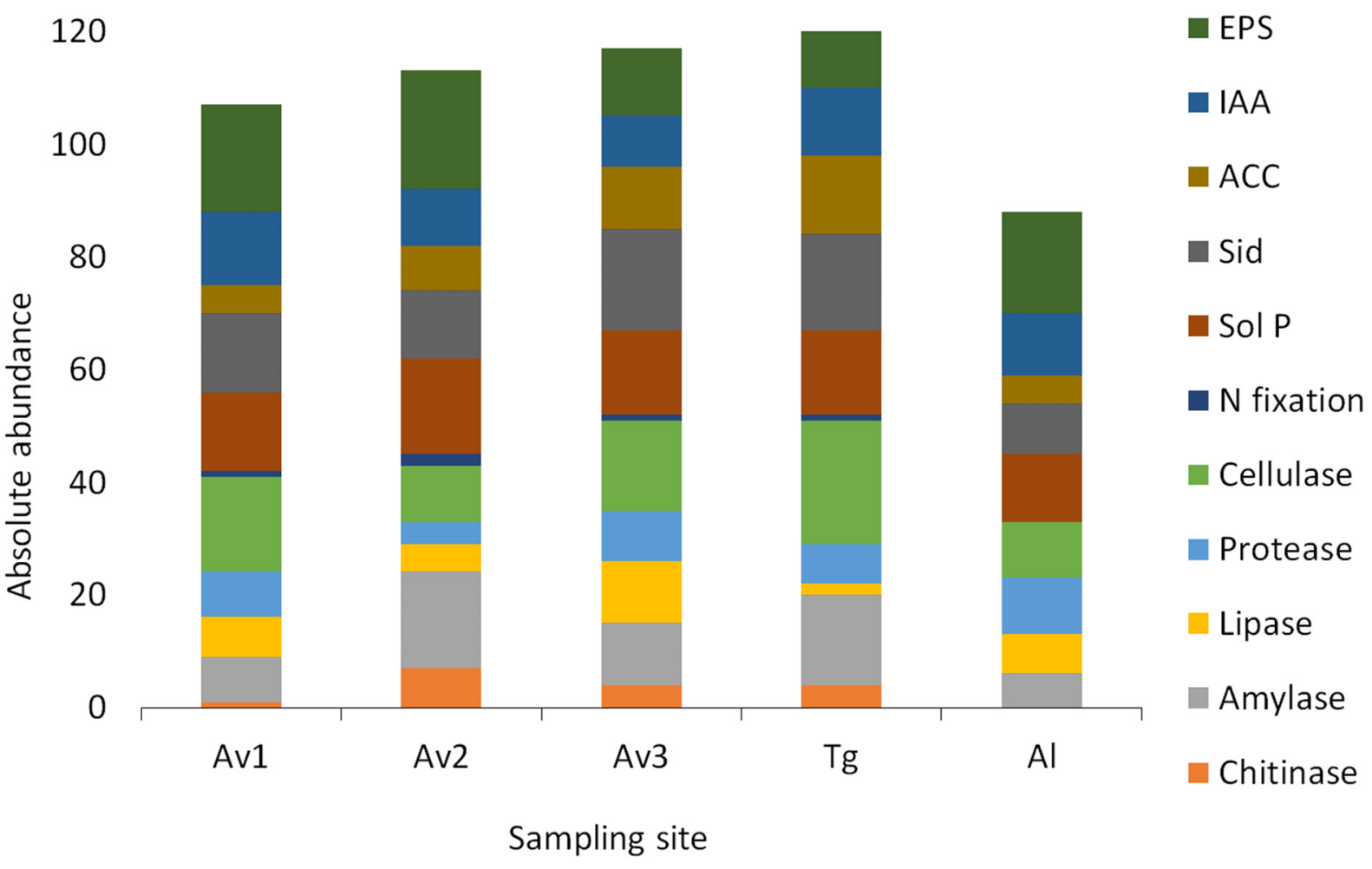

Figure A5. Distribution of isolates expressing all tested plant-growth promoting traits at each sampling site. 


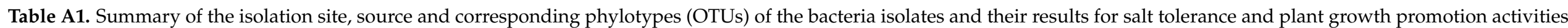
tested in this study.

\begin{tabular}{|c|c|c|c|c|c|c|c|c|c|c|c|c|c|c|c|c|}
\hline \multicolumn{3}{|c|}{ Isolates } & \multicolumn{2}{|c|}{ Identification } & \multirow[t]{2}{*}{$\begin{array}{c}\text { Limit Salt } \\
\text { Tolerance }\left(\mathrm{g} \mathrm{L}^{-1}\right)\end{array}$} & \multicolumn{5}{|c|}{ Extracellular Enzymes } & \multicolumn{6}{|c|}{ Plant-Growth Promoting Traits } \\
\hline Code & Site & Source & Phylotype & $\begin{array}{c}\text { Candidate } \\
\text { Identification a }\end{array}$ & & $Q^{1}$ & $A^{2}$ & $\mathrm{~L}^{3}$ & $\mathbf{P}^{4}$ & $\mathrm{C}^{5}$ & $\begin{array}{c}\text { P- } \\
\text { Solubilization }\end{array}$ & Siderophore & $\begin{array}{l}\text { ACC Deaminase } \\
\left(\mathrm{nm} \mathrm{mg}^{-1} \mathrm{~h}^{-1}\right)\end{array}$ & $\begin{array}{c}\text { IAA } \\
\left(\mu \mathrm{g} \mathrm{mL}^{-1}\right)\end{array}$ & $\begin{array}{c}\text { N- } \\
\text { Fixation }\end{array}$ & EPS $\left(\mathrm{OD}_{540}\right)$ \\
\hline EA1 & $\mathrm{Al}$ & E & \multirow{4}{*}{ OTU1 } & \multirow{4}{*}{$\begin{array}{c}\text { Bacillus } \\
\text { aryabhattai }\end{array}$} & 100 & - & + & - & + & + & + & - & - & - & - & $0.33 \pm 0.01$ \\
\hline EA9 & $\mathrm{Al}$ & E & & & 100 & - & - & - & - & - & + & - & - & - & - & $0.46 \pm 0.02$ \\
\hline RA2 & $\mathrm{Al}$ & $\mathrm{R}$ & & & 25 & - & + & - & + & + & + & - & - & - & - & $0.20 \pm 0.01$ \\
\hline SP20 & Av1 & $\mathrm{R}$ & & & 50 & + & + & + & + & + & + & + & - & - & - & $0.80 \pm 0.01$ \\
\hline EA4A & $\mathrm{Al}$ & $\mathrm{E}$ & \multirow{5}{*}{ OTU2 } & \multirow{5}{*}{$\begin{array}{c}\text { Bacillus } \\
\text { hwajinpoensis }\end{array}$} & 25 & - & + & - & + & + & - & + & $+(38.11 \pm 15.67)$ & - & - & $0.32 \pm 0.02$ \\
\hline EA4B & $\mathrm{Al}$ & E & & & 100 & - & + & - & - & + & - & - & - & - & - & $0.79 \pm 0.02$ \\
\hline EL9 & $\mathrm{Tg}$ & E & & & 100 & - & + & - & + & + & - & - & - & $9.81 \pm 0.46$ & - & $0.66 \pm 0.01$ \\
\hline RL11A & $\mathrm{Tg}$ & $\mathrm{R}$ & & & 100 & + & + & - & - & + & + & + & $+(22.11 \pm 5.0)$ & - & - & $0.33 \pm 0.02$ \\
\hline RL21 & $\mathrm{Tg}$ & $\mathrm{R}$ & & & 100 & - & + & - & - & + & - & + & $+^{*}(19.57 \pm 9.2)$ & - & - & $0.92 \pm 0.03$ \\
\hline EA7 & $\mathrm{Al}$ & $\mathrm{E}$ & \multirow{5}{*}{ OTU3 } & \multirow{5}{*}{$\begin{array}{l}\text { Micrococcus } \\
\text { aloeverae }\end{array}$} & 100 & - & - & - & + & + & - & + & $\begin{array}{c}\text { Doubtful }( \pm) \\
(23.01 \pm 15.22)\end{array}$ & $18.28 \pm 1.96$ & - & $0.46 \pm 0.02$ \\
\hline EH1 & Av1 & E & & & 100 & - & + & - & + & + & + & - & $+^{*}$ & $11.58 \pm 0.53$ & - & $0.70 \pm 0.01$ \\
\hline EH14 & Av1 & $\mathrm{E}$ & & & 100 & - & + & + & - & + & + & + & - & $11.00+0.00$ & - & $\begin{array}{c}0.0 .01 \\
-\end{array}$ \\
\hline EH21 & Av1 & E & & & 100 & - & - & + & + & + & - & + & $t^{*}$ & $10.98 \pm 1.34$ & - & $0.71 \pm 0.01$ \\
\hline $\mathrm{EH} 24$ & Av1 & E & & & 100 & - & - & + & - & + & - & + & $\begin{array}{c}\text { Doubtful }( \pm) \\
(12.47 \pm 7.29)\end{array}$ & - & - & $0.44 \pm 0.01$ \\
\hline EB2 & Av3 & E & OTU5 & $\begin{array}{c}\text { Halomonas } \\
\text { taeanensis }\end{array}$ & 100 & - & - & - & - & - & - & + & $+^{*}(15.98 \pm 2.3)$ & - & - & - \\
\hline EB3 & Av3 & E & OTU6 & $\begin{array}{l}\text { Brevibacterium } \\
\text { casei }\end{array}$ & 100 & - & - & - & + & + & - & + & $+(17.63 \pm 1.35)$ & $10.87 \pm 0.48$ & + & $1.24 \pm 0.03$ \\
\hline EB5 & Av3 & E & \multirow{6}{*}{ OTU7 } & \multirow{6}{*}{$\begin{array}{c}\text { Providencia } \\
\text { rettgeri }\end{array}$} & 100 & - & - & - & - & + & + & - & $+^{*}$ & $25.50 \pm 2.3$ & - & - \\
\hline EB7 & Av3 & E & & & 50 & - & - & - & - & + & + & + & $t^{*}$ & $27.85 \pm 1.37$ & - & - \\
\hline EB41B & Av3 & E & & & 100 & - & - & - & + & - & + & + & $t^{*}$ & $15.17 \pm 0.96$ & - & - \\
\hline EB40 & Av3 & E & & & 100 & - & + & - & - & - & + & + & $+^{*}(14.04 \pm 4.44)$ & $17.87 \pm 0.54$ & - & $2.39 \pm 0.1$ \\
\hline EB41A & Av3 & $\mathrm{E}$ & & & 50 & - & - & - & - & - & + & + & - & - & - & - \\
\hline EB42 & Av3 & E & & & 100 & - & - & - & - & - & + & + & - & - & - & $0.32 \pm 0.0$ \\
\hline
\end{tabular}


Table A1. Cont.

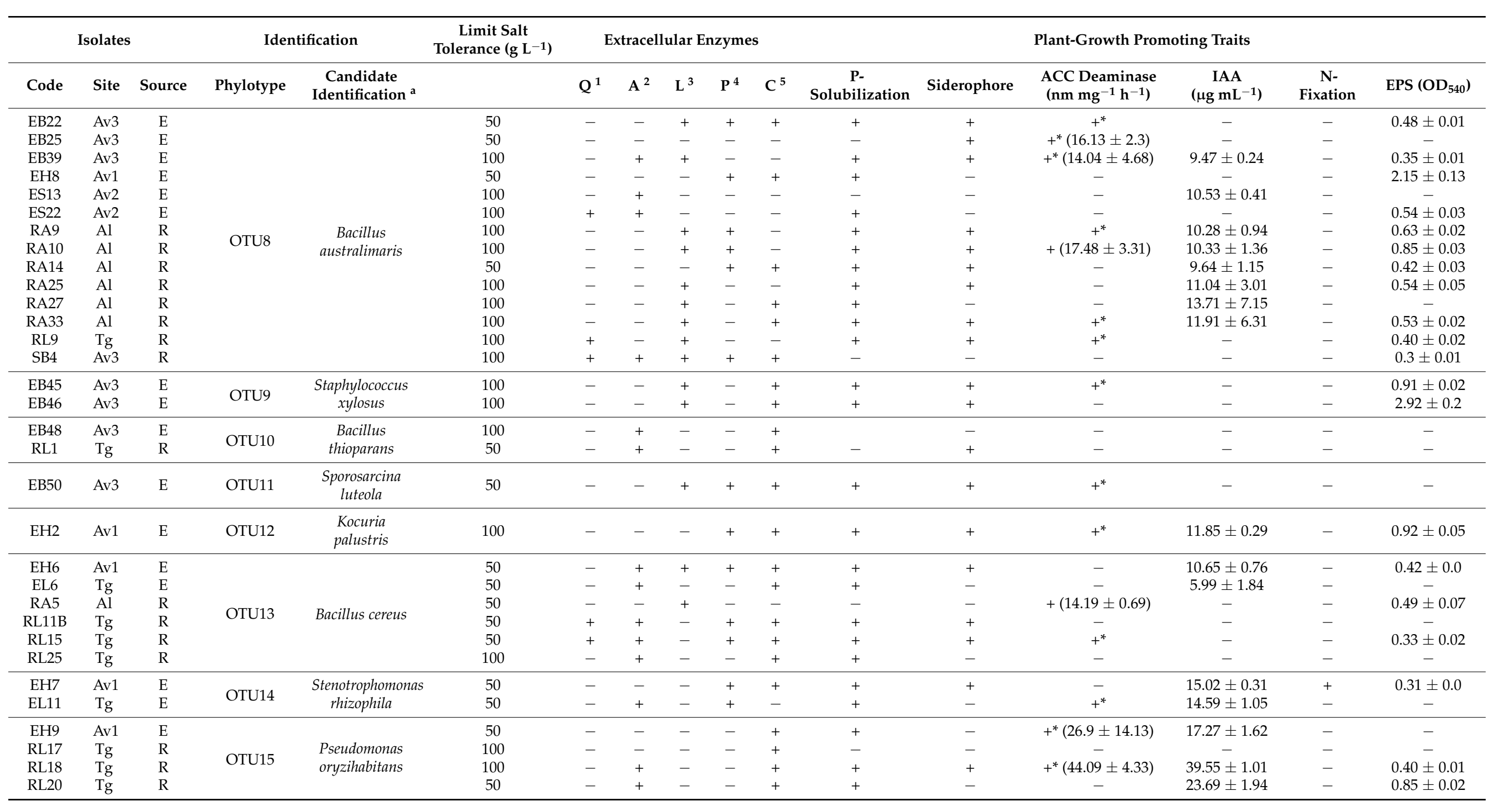


Table A1. Cont.

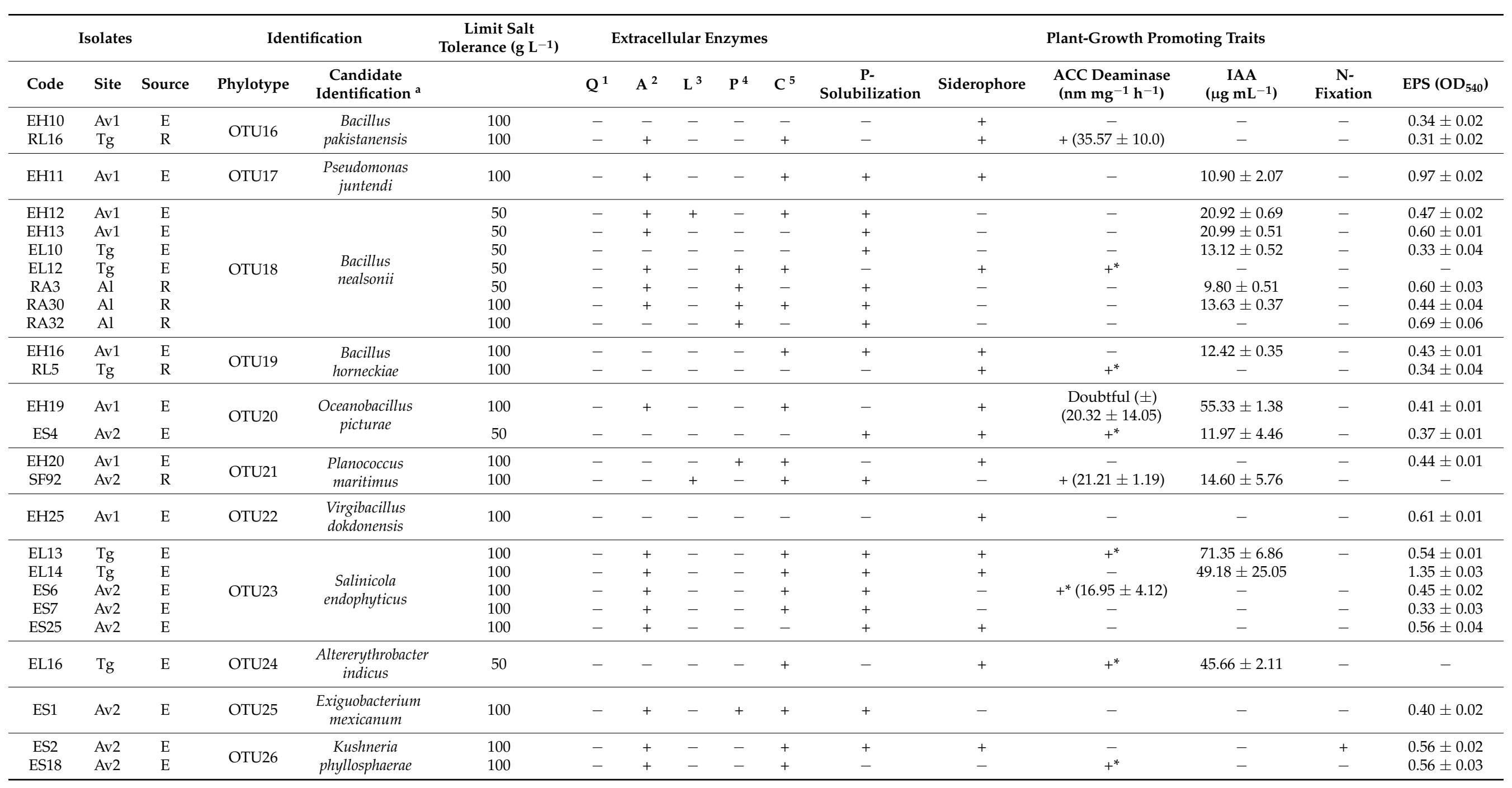


Table A1. Cont.

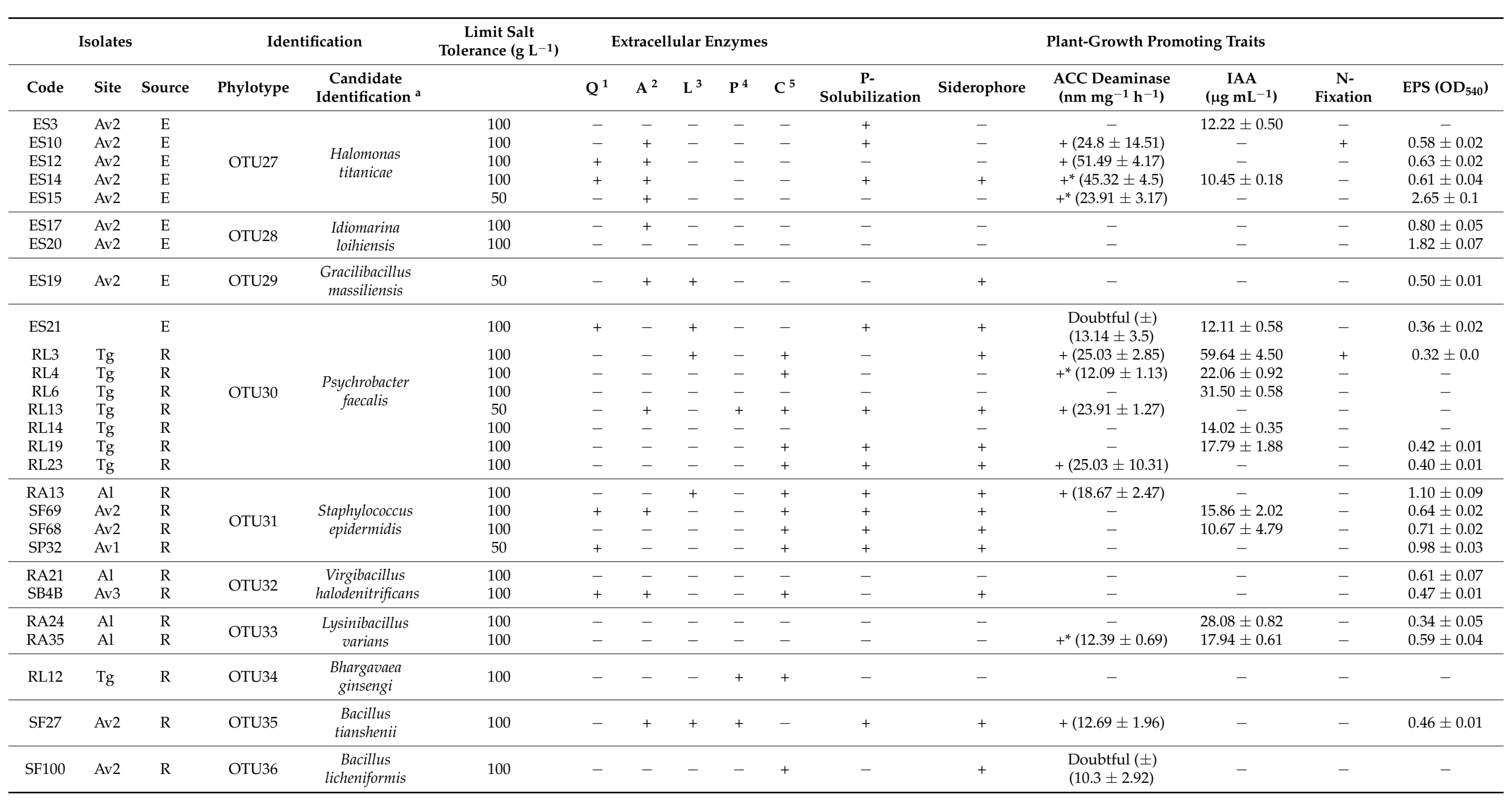


Table A1. Cont.

\begin{tabular}{|c|c|c|c|c|c|c|c|c|c|c|c|c|c|c|c|c|}
\hline \multicolumn{3}{|c|}{ Isolates } & \multicolumn{2}{|c|}{ Identification } & \multirow[t]{2}{*}{$\begin{array}{c}\text { Limit Salt } \\
\text { Tolerance }\left(\mathrm{g} \mathrm{L}^{-1}\right) \\
\end{array}$} & \multicolumn{5}{|c|}{ Extracellular Enzymes } & \multicolumn{6}{|c|}{ Plant-Growth Promoting Traits } \\
\hline Code & Site & Source & Phylotype & $\begin{array}{c}\text { Candidate } \\
\text { Identification a }\end{array}$ & & $\mathrm{Q}^{1}$ & $A^{2}$ & $\mathrm{~L}^{3}$ & $\mathrm{P}^{4}$ & $C^{5}$ & $\begin{array}{c}\text { P- } \\
\text { Solubilization }\end{array}$ & Siderophore & $\begin{array}{c}\text { ACC Deaminase } \\
\left(\mathrm{nm} \mathrm{mg}^{-1} \mathrm{~h}^{-1}\right)\end{array}$ & $\begin{array}{c}\text { IAA } \\
\left(\mu \mathrm{gLL}^{-1}\right)\end{array}$ & $\begin{array}{c}\mathrm{N}- \\
\text { Fixation }\end{array}$ & EPS $\left(\mathrm{OD}_{540}\right)$ \\
\hline SF59 & Av2 & $\mathrm{R}$ & \multirow{3}{*}{ OTU38 } & \multirow{3}{*}{$\begin{array}{c}\text { Bacillus } \\
\text { vietnamensis }\end{array}$} & 50 & + & + & + & + & + & - & - & $+(22.11 \pm 3.14)$ & - & - & $0.39 \pm 0.02$ \\
\hline SB113 & Av3 & $\mathrm{R}$ & & & 50 & - & + & + & + & + & - & + & - & - & - & $0.35 \pm 0.0$ \\
\hline SB8 & Av3 & $\mathrm{R}$ & & & 100 & - & + & + & + & - & - & + & - & - & - & - \\
\hline SF91 & Av2 & $\mathrm{R}$ & \multirow{4}{*}{ OTU39 } & \multirow{4}{*}{$\begin{array}{l}\text { Staphylococcus } \\
\text { epidermidis }\end{array}$} & 25 & - & - & - & - & - & + & + & $+(141.86 \pm 1.27)$ & $9.27 \pm 2.78$ & - & - \\
\hline SP103 & Av1 & $\mathrm{R}$ & & & 50 & - & - & - & - & - & + & - & - & $19.12 \pm 3.46$ & - & $0.39 \pm 0.01$ \\
\hline SF104 & Av2 & $\mathrm{R}$ & & & 100 & + & - & - & + & - & + & + & $+(13.81 \pm 0.95)$ & $9.79 \pm 3.98$ & - & $1.35 \pm 0.05$ \\
\hline SB112 & Av3 & $\mathrm{R}$ & & & 100 & + & - & + & - & + & + & - & - & - & - & $0.40 \pm$ \\
\hline SP86 & Av1 & $\mathrm{R}$ & OTU40 & $\begin{array}{c}\text { Virgibacillus } \\
\text { halodenitrificans }\end{array}$ & 100 & - & - & + & - & + & - & - & - & $11.34 \pm 5.3$ & - & $1.58 \pm 0.06$ \\
\hline SB102 & Av3 & $\mathrm{R}$ & OTU41 & $\begin{array}{l}\text { Bacillus } \\
\text { infantis }\end{array}$ & 100 & + & + & + & + & + & - & + & $\begin{array}{l}\text { Doubtful }(+-+) \\
(12.39 \pm 2.99)\end{array}$ & $25.19 \pm 5.36$ & - & - \\
\hline $\begin{array}{c}\text { Control } \\
(+)\end{array}$ & & & & $\begin{array}{l}\text { Pseudomonas } \\
\text { aeruginosa }\end{array}$ & & & & & & & & & 115.4 & $47.26 \pm 0.66$ & & $0.66 \pm 0.02$ \\
\hline
\end{tabular}

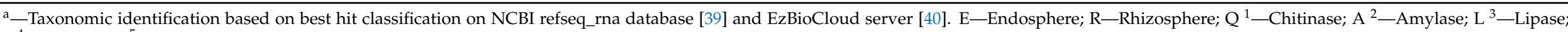

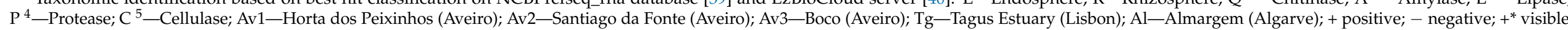
growth on solid DF +ACC medium. 
Table A2. Percentage of isolates expressing each PGP trait per sampling site.

\begin{tabular}{cccccc}
\hline & Av1 & Av2 & Av3 & Tg & Al \\
\hline Chitinase & $5 \%$ & $27 \%$ & $16 \%$ & $14 \%$ & $0 \%$ \\
Amylase & $38 \%$ & $65 \%$ & $44 \%$ & $57 \%$ & $30 \%$ \\
Lipase & $33 \%$ & $19 \%$ & $44 \%$ & $7 \%$ & $35 \%$ \\
Protease & $38 \%$ & $15 \%$ & $36 \%$ & $25 \%$ & $50 \%$ \\
Cellulase & $81 \%$ & $38 \%$ & $64 \%$ & $79 \%$ & $50 \%$ \\
N fixation & $5 \%$ & $8 \%$ & $4 \%$ & $4 \%$ & $0 \%$ \\
Sol P & $67 \%$ & $65 \%$ & $60 \%$ & $54 \%$ & $60 \%$ \\
Siderophores & $67 \%$ & $46 \%$ & $72 \%$ & $61 \%$ & $45 \%$ \\
ACC deaminase & $24 \%$ & $42 \%$ & $44 \%$ & $75 \%$ & $35 \%$ \\
IAA & $62 \%$ & $38 \%$ & $36 \%$ & $43 \%$ & $55 \%$ \\
EPS & $90 \%$ & $81 \%$ & $48 \%$ & $54 \%$ & $90 \%$ \\
\hline
\end{tabular}

\section{References}

1. Yuan, Z.; Druzhinina, I.S.; Labbé, J.; Redman, R.; Qin, Y.; Rodriguez, R.; Zhang, C.; Tuskan, G.A.; Lin, F. Specialized microbiome of a halophyte and its role in helping non-host plants to withstand salinity. Sci. Rep. 2016, 6. [CrossRef] [PubMed]

2. Flowers, T.J.; Colmer, T.D. Salinity tolerance in halophytes. New Phytol. 2008, 179, 945-963. [CrossRef]

3. Volkov, V.; Beilby, M.J. Editorial: Salinity tolerance in plants: Mechanisms and regulation of ion transport. Front. Plant Sci. 2017, 8, 1795. [CrossRef] [PubMed]

4. Sgroy, V.; Cassán, F.; Masciarelli, O.; Del Papa, M.F.; Lagares, A.; Luna, V. Isolation and characterization of endophytic plant growth-promoting (PGPB) or stress homeostasis-regulating (PSHB) bacteria associated to the halophyte Prosopis strombulifera. Appl. Microbiol. Biotechnol. 2009, 85, 371-381. [CrossRef]

5. Bragina, A.; Oberauner-Wappis, L.; Zachow, C.; Halwachs, B.; Thallinger, G.G.; Müller, H.; Berg, G. The Sphagnum microbiome supports bog ecosystem functioning under extreme conditions. Mol. Ecol. 2014, 23, 4498-4510. [CrossRef] [PubMed]

6. Trognitz, F.; Hackl, E.; Widhalm, S.; Sessitsch, A. The role of plant-microbiome interactions in weed establishment and control. FEMS Microbiol. Ecol. 2016, 92, 1-15. [CrossRef]

7. Hartman, K.; van der Heijden, M.G.A.; Roussely-Provent, V.; Walser, J.C.; Schlaeppi, K. Deciphering composition and function of the root microbiome of a legume plant. Microbiome 2017, 5, 1-13. [CrossRef] [PubMed]

8. Egamberdieva, D.; Wirth, S.; Bellingrath-Kimura, S.D.; Mishra, J.; Arora, N.K. Salt-Tolerant Plant Growth Promoting Rhizobacteria for Enhancing Crop Productivity of Saline Soils. Front. Microbiol. 2019, 10, 1-18. [CrossRef]

9. Dimkpa, C.; Weinand, T.; Asch, F. Plant-rhizobacteria interactions alleviate abiotic stress conditions. Plant Cell Environ. 2009, 32, 1682-1694. [CrossRef] [PubMed]

10. Jha, B.; Gontia, I.; Hartmann, A. The roots of the halophyte Salicornia brachiata are a source of new halotolerant diazotrophic bacteria with plant growth-promoting potential. Plant Soil 2012, 356, 265-277. [CrossRef]

11. Ruppel, S.; Franken, P.; Witzel, K. Properties of the halophyte microbiome and their implications for plant salt tolerance. Funct. Plant Biol. 2013, 40, 940-951. [CrossRef]

12. Castroviejo, S. Salicornia L. Stud. Plant Sci. 1991, 2, 69. [CrossRef]

13. Silva, H.; Caldeira, G.; Freitas, H. Salicornia ramosissima population dynamics and tolerance of salinity. Ecol. Res. 2007, 22, 125-134. [CrossRef]

14. Jefferies, R.L.; Gottlieb, L.D. Genetic differentiation of the microspecies Salicornia europaea L. (sensu stricto) and S. ramosissima. J. Woods. New Phytol. 1982. [CrossRef]

15. Milić, D.; Luković, J.; Dan, M.; Zorić, L.; Obreht, D.; Veselić, S.; Anačkov, G.; Petanidou, T. Identification of salicornia population: Anatomical characterization and RAPD fingerprinting. Arch. Biol. Sci. 2011. [CrossRef]

16. Ingrouille, M.; Pearson, J. The pattern of morphological variation in the Salicornia europaea L. aggregate (Chenopodiaceae). Watsonia 1987.

17. Bae, J.Y.; Park, L.Y.; Lee, S.H. Effect of Salicornia herbacea L. powder on the quality characteristics of bread. J. Korean Soc. Food Sci. Nutr. 2008. [CrossRef]

18. Lee, J.H.; Kim, H.J.; Rhim, J.W. Vacuum drying characteristics of Salicornia herbacea L. J. Agric. Sci. Technol. 2012, 14, 587-598.

19. Elsebaie, E.M.; Elsanat, S.Y.; Gouda, M.S.; Elnemr, K.M. Oil and Fatty Acids Composition in Glasswort (Salicornia Fruticosa) Seeds. IOSR J. Appl. Chem. 2013, 4, 06-09. [CrossRef]

20. Isca, V.M.S.; Seca, A.M.L.; Pinto, D.C.G.A.; Silva, H.; Silva, A.M.S. Lipophilic profile of the edible halophyte Salicornia ramosissima. Food Chem. 2014, 165, 330-336. [CrossRef] [PubMed]

21. Shi, Y.W.; Lou, K.; Li, C.; Wang, L.; Zhao, Z.Y.; Zhao, S.; Tian, C.Y. Illumina-based analysis of bacterial diversity related to halophytes Salicornia europaea and Sueada aralocaspica. J. Microbiol. 2015, 53, 678-685. [CrossRef]

22. Furtado, B.U.; Gołebiewski, M.; Skorupa, M.; Hulisz, P.; Hrynkiewicz, K. Bacterial and fungal endophytic microbiomes of Salicornia europaea. Appl. Environ. Microbiol. 2019, 85, 1-18. [CrossRef] [PubMed] 
23. Szymańska, S.; Borruso, L.; Brusetti, L.; Hulisz, P.; Furtado, B.; Hrynkiewicz, K. Bacterial microbiome of root-associated endophytes of Salicornia europaea in correspondence to different levels of salinity. Environ. Sci. Pollut. Res. 2018, 25, 25420-25431. [CrossRef]

24. Zhao, S.; Zhou, N.; Zhao, Z.Y.; Zhang, K.; Wu, G.H.; Tian, C.Y. Isolation of Endophytic Plant Growth-Promoting Bacteria Associated with the Halophyte Salicornia europaea and Evaluation of their Promoting Activity Under Salt Stress. Curr. Microbiol. 2016, 73, 574-581. [CrossRef] [PubMed]

25. Razzaghi Komaresofla, B.; Alikhani, H.A.; Etesami, H.; Khoshkholgh-Sima, N.A. Improved growth and salinity tolerance of the halophyte Salicornia sp. by co-inoculation with endophytic and rhizosphere bacteria. Appl. Soil Ecol. 2019, 138, 160-170. [CrossRef]

26. Figueira, C.; Ferreira, M.J.; Silva, H.; Cunha, A. Improved germination efficiency of Salicornia ramosissima seeds inoculated with Bacillus aryabhattai SP1016-20. Ann. Appl. Biol. 2019, 174, 319-328. [CrossRef]

27. Mesa-Marín, J.; Pérez-Romero, J.A.; Mateos-Naranjo, E.; Bernabeu-Meana, M.; Pajuelo, E.; Rodríguez-Llorente, I.D.; RedondoGómez, S. Effect of plant growth-promoting rhizobacteria on salicornia ramosissima seed germination under salinity, $\mathrm{CO}_{2}$ and temperature stress. Agronomy 2019, 9, 655. [CrossRef]

28. Rodríguez, M.; Torres, M.; Blanco, L.; Béjar, V.; Sampedro, I.; Llamas, I. Plant growth-promoting activity and quorum quenchingmediated biocontrol of bacterial phytopathogens by Pseudomonas segetis strain P6. Sci. Rep. 2020, 10, 1-12. [CrossRef]

29. Piernik, A.; Hrynkiewicz, K.; Wojciechowska, A.; Szymańska, S.; Lis, M.I.; Muscolo, A. Effect of halotolerant endophytic bacteria isolated from Salicornia europaea L. on the growth of fodder beet (Beta vulgaris L.) under salt stress. Arch. Agron. Soil Sci. 2017, 63, 1404-1418. [CrossRef]

30. Hrynkiewicz, K.; Patz, S.; Ruppel, S. Salicornia europaea L. as an underutilized saline-tolerant plant inhabited by endophytic diazotrophs. J. Adv. Res. 2019, 19, 49-56. [CrossRef]

31. Schulte, E.E.; Hopkins, B.G. Estimation of Soil Organic Matter by Weight Loss-On-Ignition. In Soil Organic Matter: Analysis and Interpretation; Magdoff, F., Tabatabai, M.A., Hanlon, E.A., Eds.; Soil Science Society of America: Madison, WI, USA, 1996; Volume 049, pp. 21-31.

32. Zaman, M.; Shahid, S.A.; Heng, L. Guideline for Salinity Assessment, Mitigation and Adaptation Using Nuclear and Related Techniques; Springer: Berlin, Germany, 2018; ISBN 9783319961897.

33. Sonmez, S.; Buyuktas, D.; Okturen, F.; Citak, S. Assessment of different soil to water ratios (1:1, 1:2.5, 1:5) in soil salinity studies. Geoderma 2008. [CrossRef]

34. Barillot, C.D.C.; Sarde, C.O.; Bert, V.; Tarnaud, E.; Cochet, N. A standardized method for the sampling of rhizosphere and rhizoplan soil bacteria associated to a herbaceous root system. Ann. Microbiol. 2013, 63, 471-476. [CrossRef]

35. Oren, A. Life at High Salt Concentrations. Prokaryotes 2006, 3, 263-282.

36. Szymańska, S.; Płociniczak, T.; Piotrowska-Seget, Z.; Hrynkiewicz, K. Endophytic and rhizosphere bacteria associated with the roots of the halophyte Salicornia europaea L.-Community structure and metabolic potential. Microbiol. Res. 2016, 192, 37-51. [CrossRef] [PubMed]

37. Weisburg, W.G.; Barns, S.M.; Pelletier, D.A.; Lane, D.J. $16 \mathrm{~S}$ ribosomal DNA amplification for phylogenetic study. J. Bacteriol. 1991, 173, 697-703. [CrossRef] [PubMed]

38. Cole, J.R.; Wang, Q.; Fish, J.A.; Chai, B.; McGarrell, D.M.; Sun, Y.; Brown, C.T.; Porras-Alfaro, A.; Kuske, C.R.; Tiedje, J.M Ribosomal Database Project: Data and tools for high throughput rRNA analysis. Nucleic Acids Res. 2014. [CrossRef]

39. Agarwala, R.; Barrett, T.; Beck, J.; Benson, D.A.; Bollin, C.; Bolton, E.; Bourexis, D.; Brister, J.R.; Bryant, S.H.; Canese, K.; et al. Database Resources of the National Center for Biotechnology Information. Nucleic Acids Res. 2017. [CrossRef]

40. Yoon, S.H.; Ha, S.M.; Kwon, S.; Lim, J.; Kim, Y.; Seo, H.; Chun, J. Introducing EzBioCloud: A taxonomically united database of 16S rRNA gene sequences and whole-genome assemblies. Int. J. Syst. Evol. Microbiol. 2017. [CrossRef]

41. Brígido, C.; Singh, S.; Menéndez, E.; Tavares, M.J.; Glick, B.R.; Do Rosário Félix, M.; Oliveira, S.; Carvalho, M. Diversity and functionality of culturable endophytic bacterial communities in chickpea plants. Plants 2019, 8, 42. [CrossRef]

42. Kouker, G.; Jaeger, K.E. Specific and sensitive plate assay for bacterial lipases. Appl. Environ. Microbiol. 1987, 53, 211-213. [CrossRef]

43. Dunne, C.; Crowley, J.J.; Moënne-Loccoz, Y.; Dowling, D.N.; De Bruijn, F.J.; O'Gara, F. Biological control of Pythium ultimum by Stenotrophomonas maltophilia W81 is mediated by an extracellular proteolytic activity. Microbiology 1997, 143, 3921-3931. [CrossRef] [PubMed]

44. Gordon, S.A.; Weber, R.P. Colorimetric Estimation of Inodoleacetic Acid. Plant Physiol. 1951, 26, 192-195. [CrossRef] [PubMed]

45. Khare, E.; Arora, N. Effect of Indole-3-Acetic Acid (IAA) Produced by Pseudomonas aeruginosa in Suppression of Charcoal Rot Disease of Chickpea. Curr. Microbiol. 2010, 61, 64-68. [CrossRef] [PubMed]

46. Penrose, D.M.; Glick, B.R. Methods for isolating and characterizing ACC deaminase-containing plant growth-promoting rhizobacteria. Physiol. Plant. 2003, 118, 10-15. [CrossRef] [PubMed]

47. Honma, M.; Smmomura, T. Metabolism of 1-aminocyclopropane-1-carboxylic acid. Agric. Biol. Chem. 1978, 42, 1825-1831. [CrossRef]

48. Balado, M.; Souto, A.; Vences, A.; Careaga, V.P.; Valderrama, K.; Segade, Y.; Rodríguez, J.; Osorio, C.R.; Jiménez, C.; Lemos, M.L. Two Catechol Siderophores, Acinetobactin and Amonabactin, Are Simultaneously Produced by Aeromonas salmonicida subsp. salmonicida Sharing Part of the Biosynthetic Pathway. ACS Chem. Biol. 2015, 10, 2850-2860. [CrossRef] 
49. Pérez-Miranda, S.; Cabirol, N.; George-Téllez, R.; Zamudio-Rivera, L.S.; Fernández, F.J. O-CAS, a fast and universal method for siderophore detection. J. Microbiol. Methods 2007, 70, 127-131. [CrossRef]

50. Vazquez, P.; Holguin, G.; Puente, M.E.; Lopez-Cortes, A.; Bashan, Y. Phosphate-solubilizing microorganisms associated with the rhizosphere of mangroves in a semiarid coastal lagoon. Biol. Fertil. Soils 2000, 30, 460-468. [CrossRef]

51. Paul, D.; Sinha, S.N. Isolation and characterization of phosphate solubilizing bacterium Pseudomonas aeruginosa KUPSB12 with antibacterial potential from river Ganga, India. Ann. Agrar. Sci. 2017, 15, 130-136. [CrossRef]

52. Chakraborty, U.; Roy, S.; Chakraborty, A.; Dey, P.; Chakraborty, B. Plant Growth Promotion and Amelioration of Salinity Stress in Crop Plants by a Salt-Tolerant Bacterium. Rec. Res. Sci. Tech. 2011, 3, 61-70.

53. Yu, S.S.; Kyaw, E.P.; Lynn, T.; Latt, Z.K.; Aung, A.; Sev, T.M.; Thet, M. The correlation of carbon source and ammonium accumulation in culture broth by nitrogen-fixing bacterial isolates The correlation of carbon source and ammonium accumulation in culture broth by nitrogen-fixing bacterial isolates. J. Sci. Innov. Res. 2017, 6, 63-67.

54. Stepanović, S.; Vuković, D.; Dakić, I.; Savić, B.; Švabić-Vlahović, M. A modified microtiter-plate test for quantification of staphylococcal biofilm formation. J. Microbiol. Methods 2000, 40, 175-179. [CrossRef]

55. Myszka, K.; Czaczyk, K. Characterization of adhesive exopolysaccharide (EPS) produced by Pseudomonas aeruginosa under starvation conditions. Curr. Microbiol. 2009, 58, 541-546. [CrossRef] [PubMed]

56. R Core Team. R: A Language and Environment for Statistical Computing. 2014. Available online: https://www.R-project.org (accessed on 23 February 2021).

57. Oksanen, J.; Blanchet, F.G.; Kindt, R.; Legendre, P.; Minchin, P.R.; O’Hara, R.B.; Simpson, G.L.; Solymos, P.; Stevens, M.H.; Wagner, H. Vegan: Community Ecology Package. R Package Version 2.0-9. Available online: https://CRAN.R-project.org/ package=vegan (accessed on 23 February 2021).

58. USDA. Soil Survey Manual Agriculture. Handbook 18; USDA Natural Resources Conservation Service: Washington, DC, USA, 2017.

59. Rhoades, J.; Kandiah, A.; Mashali, A. The Use of Saline Waters for Crop Production; Food and Agriculture Organization of the United Nations: Rome, Italy, 1992; ISBN 9251032378.

60. Etesami, H.; Beattie, G.A. Mining halophytes for plant growth-promoting halotolerant bacteria to enhance the salinity tolerance of non-halophytic crops. Front. Microbiol. 2018, 9. [CrossRef] [PubMed]

61. Szoboszlay, M.; Näther, A.; Liu, B.; Carrillo, A.; Castellanos, T.; Smalla, K.; Jia, Z.; Tebbe, C.C. Contrasting microbial community responses to salinization and straw amendment in a semiarid bare soil and its wheat rhizosphere. Sci. Rep. 2019. [CrossRef] [PubMed]

62. Garza, D.R.; Dutilh, B.E. From cultured to uncultured genome sequences: Metagenomics and modeling microbial ecosystems. Cell. Mol. Life Sci. 2015, 72, 4287-4308. [CrossRef]

63. Yamamoto, K.; Shiwa, Y.; Ishige, T.; Sakamoto, H.; Tanaka, K.; Uchino, M.; Tanaka, N.; Oguri, S.; Saitoh, H.; Tsushima, S. Bacterial diversity associated with the rhizosphere and endosphere of two halophytes: Glaux maritima and Salicornia europaea. Front. Microbiol. 2018, 9, 1-12. [CrossRef]

64. Ravikumar, S.; Inbaneson, S.J.; Uthiraselvam, M.; Priya, S.R.; Ramu, A.; Banerjee, M.B. Diversity of Endophytic Actinomycetes from Karangkadu Mangrove Ecosystem and Its Antibacterial Potential Against Bacterial Pathogens. J. Pharm. Res. 2011, 4, 294-296.

65. De Ridder-Duine, A.S.; Kowalchuk, G.A.; Klein Gunnewiek, P.J.A.; Smant, W.; Van Veen, J.A.; De Boer, W. Rhizosphere bacterial community composition in natural stands of Carex arenaria (sand sedge) is determined by bulk soil community composition. Soil Biol. Biochem. 2005, 37, 349-357. [CrossRef]

66. Chaudhary, D.R.; Saxena, J.; Lorenz, N.; Dick, L.K.; Dick, R.P. Microbial Profiles of Rhizosphere and Bulk Soil Microbial Communities of Biofuel Crops Switchgrass (Panicum virgatum L.) and Jatropha (Jatropha curcas L.). Appl. Environ. Soil Sci. 2012, 2012, 906864. [CrossRef]

67. Shi, J.-Y.; Yuan, X.-F.; Lin, H.-R.; Yang, Y.-Q.; Li, Z.-Y. Differences in soil properties and bacterial communities between the rhizosphere and bulk soil and among different production areas of the medicinal plant Fritillaria thunbergii. Int. J. Mol. Sci. 2011, 12, 3770-3785. [CrossRef] [PubMed]

68. Mahmoudi, N.; Beaupré, S.R.; Steen, A.D.; Pearson, A. Sequential bioavailability of sedimentary organic matter to heterotrophic bacteria. Environ. Microbiol. 2017. [CrossRef] [PubMed]

69. Fidalgo, C.; Henriques, I.; Rocha, J.; Tacão, M.; Alves, A. Culturable endophytic bacteria from the salt marsh plant Halimione portulacoides: Phylogenetic diversity, functional characterization, and influence of metal(loid) contamination. Environ. Sci. Pollut. Res. 2016, 23, 10200-10214. [CrossRef] [PubMed]

70. Menendez, E.; Garcia-Fraile, P.; Rivas, R. Biotechnological applications of bacterial cellulases. AIMS Bioeng. 2015, 2, 163-182. [CrossRef]

71. Olanrewaju, O.S.; Glick, B.R.; Babalola, O.O. Mechanisms of action of plant growth promoting bacteria. World J. Microbiol. Biotechnol. 2012, 1, 197. [CrossRef]

72. Glick, B.R.; Glick, B.R. Plant Growth-Promoting Bacteria: Mechanisms and Applications. Scientifica 2012, 2012, 1-15. [CrossRef]

73. Kaur, T.; Sharma, D.; Kaur, A.; Manhas, R.K. Antagonistic and plant growth promoting activities of endophytic and soil actinomycetes. Arch. Phytopathol. Plant Prot. 2013, 46, 1756-1768. [CrossRef]

74. Etesami, H.; Alikhani, H.A. Bacillus species as the most promising bacterial biocontrol agents in rhizosphere and endorhiza of plants grown in rotation with each other. Eur. J. Plant Pathol. 2018. [CrossRef] 
75. Szymańska, S.; Płociniczak, T.; Piotrowska-Seget, Z.; Złoch, M.; Ruppel, S.; Hrynkiewicz, K. Metabolic potential and community structure of endophytic and rhizosphere bacteria associated with the roots of the halophyte Aster tripolium L. Microbiol. Res. 2016, 182, 68-79. [CrossRef] [PubMed]

76. Siddikee, M.A.; Tipayno, S.C.; Kim, K.; Chung, J.; Sa, T. Influence of varying degree of salinity-sodicity stress on enzyme activities and bacterial populations of coastal soils of yellow sea, South Korea. J. Microbiol. Biotechnol. 2011, 21, 341-346. [CrossRef]

77. Costa, O.Y.A.; Raaijmakers, J.M.; Kuramae, E.E. Microbial extracellular polymeric substances: Ecological function and impact on soil aggregation. Front. Microbiol. 2018, 9, 1636. [CrossRef]

78. Upadhyay, S.K.; Singh, J.S.; Singh, D.P. Exopolysaccharide-producing plant growth-promoting rhizobacteria under salinity condition. Pedosphere 2011. [CrossRef]

79. Bremer, E.; Krämer, R. Responses of microorganisms to osmotic stress. Annu. Rev. Microbiol. 2019, 73, 313-334. [CrossRef] [PubMed]

80. Gupta, G.; Snehi, S.K.; Singh, V. Role of PGPR in Biofilm Formations and Its Importance in Plant Health. Biofilms Plant Soil Health 2017, 27, 27-40.

81. Khan, M.Z.; Islam, M.A.; Azom, M.G.; Amin, M.S. Short Term Influence of Salinity on Uptake of Phosphorus by Ipomoea aquatica. Int. J. Plant Soil Sci. 2018, 25, 1-9. [CrossRef]

82. Qin, Y.; Druzhinina, I.S.; Pan, X.; Yuan, Z. Microbially Mediated Plant Salt Tolerance and Microbiome-based Solutions for Saline Agriculture. Biotechnol. Adv. 2016, 34, 1245-1259. [CrossRef] [PubMed]

83. Rodríguez, H.; Fraga, R. Phosphate solubilizing bacteria and their role in plant growth promotion. Biotechnol. Adv. 1999, 17, 319-339. [CrossRef]

84. Yi, Y.; Huang, W.; Ge, Y. Exopolysaccharide: A novel important factor in the microbial dissolution of tricalcium phosphate. World J. Microbiol. Biotechnol. 2008, 24, 1059-1065. [CrossRef]

85. Hamdali, H.; Bouizgarne, B.; Hafidi, M.; Lebrihi, A.; Virolle, M.J.; Ouhdouch, Y. Screening for rock phosphate solubilizing Actinomycetes from Moroccan phosphate mines. Appl. Soil Ecol. 2008, 38, 12-19. [CrossRef]

86. Hussain, R.M. The Effect of Phosphorus in Nitrogen Fixation in Legumes. Agric. Res. Technol. Open Access J. 2017, 5, 12-14. [CrossRef]

87. Rotaru, V.; Sinclair, T.R. Interactive influence of phosphorus and iron on nitrogen fixation by soybean. Environ. Exp. Bot. 2009, 66, 94-99. [CrossRef]

88. Mapelli, F.; Marasco, R.; Rolli, E.; Barbato, M.; Cherif, H.; Guesmi, A.; Ouzari, I.; Daffonchio, D.; Borin, S. Potential for plant growth promotion of rhizobacteria associated with Salicornia growing in Tunisian hypersaline soils. BioMed Res. Int. 2013, 2013. [CrossRef]

89. Navarro-Noya, Y.E.; Luna-Guido, M.; Dendooven, L. Cultivable Nitrogen Fixing Bacteria from Extremely Alkaline-Saline Soils. Adv. Microbiol. 2016, 6, 412-423. [CrossRef]

90. Kayasth, M.; Gera, R.; Dudeja, S.S.; Sharma, P.K.; Kumar, V. Studies on salinization in Haryana soils on free-living nitrogen-fixing bacterial populations and their activity. J. Basic Microbiol. 2014, 54, 170-179. [CrossRef]

91. Jones, K. Nitrogen Fixation in a Salt Marsh. J. Ecol. 1974, 62, 553-565. [CrossRef]

92. Elmerich, C.; Newton, W.E. Associative and Endophytic Nitrogen-fixing Bacteria and Cyanobacterial Associations. Assoc. Endophytic Nitrogen-Fixing Bact. Cyanobacterial Assoc. 2007. [CrossRef]

93. Currin, C.A.; Paerl, H.W. Environmental and physiological controls on diel patterns of N2 fixation in epiphytic cyanobacterial communities. Microb. Ecol. 1998, 35, 34-45. [CrossRef] [PubMed]

94. Etesami, H.; Alikhani, H.A.; Hosseini, H.M. Indole-3-acetic acid (IAA) production trait, a useful screening to select endophytic and rhizosphere competent bacteria for rice growth promoting agents. MethodsX 2015, 2, 72-78. [CrossRef]

95. Leontidou, K.; Genitsaris, S.; Papadopoulou, A.; Kamou, N.; Bosmali, I.; Matsi, T.; Madesis, P.; Vokou, D.; Karamanoli, K.; Mellidou, I. Plant growth promoting rhizobacteria isolated from halophytes and drought-tolerant plants: Genomic characterisation and exploration of phyto-beneficial traits. Sci. Rep. 2020, 10, 14857. [CrossRef] [PubMed]

96. Glick, B.R.; Penrose, D.M.; Li, J. A model for the lowering of plant ethylene concentrations by plant growth-promoting bacteria. $J$. Theor. Biol. 1998, 190, 63-68. [CrossRef]

97. Oliveira, A.L.M.; Canuto, E.L.; Silva, E.E.; Reis, V.M.; Baldani, J.I. Survival of endophytic diazotrophic bacteria in soil under different moisture levels. Braz. J. Microbiol. 2004. [CrossRef]

98. Han, L.L.; Wang, Q.; Shen, J.P.; Di, H.J.; Wang, J.T.; Wei, W.X.; Fang, Y.T.; Zhang, L.M.; He, J.Z. Multiple factors drive the abundance and diversity of the diazotrophic community in typical farmland soils of China. FEMS Microbiol. Ecol. 2019. [CrossRef] [PubMed] 